\title{
Audit Committee Formation: The Case of Poland ${ }^{1}$
}

\author{
Karolina Puławska², Dorota Dobija ${ }^{3}$, Katarzyna Piotrowska ${ }^{4}$, Grygorii Kravchenko ${ }^{5}$
}

Submitted: 18.07.2020. Accepted: 17.05.2021

\section{Abstract}

Purpose: This study investigates the determinants of audit committee (AC) formation in a semi-mandatory setting of a European economy, in which ownership and control are predominantly in the hands of families and business groups, and the voluntary practice of forming an AC has not been widely accepted.

Methodology: This research uses a sample of Polish nonfinancial firms listed on the Warsaw Stock Exchange (WSE) in 2008-2015. The study implemented logistic regression to test the role of the supervisory board (SB) and companies' compositional characteristics in AC creation.

Findings: Primary analysis provided evidence of an inverted association between commonly accepted determinants of AC formation - such as the number of independent members on the supervisory board (SB) - and accounting and finance expertise of the SB members. The study also revealed that companies with foreign ownership are more likely to have an AC.

Originality: This study indicates an important relationship between the existence of other SB committees as a meaningful determinant of AC formation. This article is valuable for supervisory bodies and regulators as they provide insights into factors that influence audit committee formation.

Keywords: audit committee, emerging European economy, supervisory board, ownership, board characteristics.

JEL: M19, M41, M42

\footnotetext{
Research financed by the National Science Center, Poland, grant number 2015/19/B/HS4/00118. Data Availability A summary of the data is available from the authors.

2 Corresponding author, Kozminski University, 59 Jagiellonska St., 03-301 Warsaw, e-mail: k.pulawska@kozminski.edu.pl.

3 Kozminski University, 59 Jagiellonska St., 03-301 Warsaw, e-mail: dobija.dorota@kozminski.edu.pl, https://0000-0003-2957-6882.

4 Kozminski University, 59 Jagiellonska St., 03-301 Warsaw, e-mail: kpiotrowska@kozminski.edu.pl.

5 Kozminski University, 59 Jagiellonska St., 03-301 Warsaw, e-mail: gkravchenko@kozminski.edu.pl; https://0rcid.org/0000-0001-5269-6300.
} 


\section{Introduction}

Despite the isomorphic pressures imposed by the European Union (EU) regulation (Official Journal of the EU, 2006), audit committee (AC) practices vary across the EU member states (Collier and Zaman, 2005), among which Poland adopted a hybrid model of corporate governance (Yeoh, 2007). For Continental Europe, the concept of an AC has not traditionally been part of the specific governance bundle. Therefore, an AC may be an effective governance mechanism in the Anglo-Saxon world, but in civil law countries, it is difficult to enforce new practices (Köhler, 2005) as laws can only be passed by the legislature. Thus, the main role and advantage of having an AC is to provide efficient internal control and increase financial reporting quality (Dobija, 2015; Putri and Prasetyo, 2020; Mardjono et al., 2020). Therefore, we argue that shifting toward shareholder value, corporate governance systems experiment with a hybridization process, which means mixing Continental Europe practices with shareholder practices, such as the AC formation, developed in Anglo-American economies.

This study investigates the determinants of AC formation in the semi-mandatory setting of a European economy: Poland. We consider the setting as semi-mandatory because only companies with more than five members on the supervisory board ${ }^{6}$ (SB) are required to have an AC. However, companies with five or fewer members on the $\mathrm{SB}$ can form an AC but are not required to do so. This article investigates the case of a semi-mandatory setting after the implementation of the EU Eighth Directive for the national regulation in the case of a two-tier governance model. The major objective of the Eighth EU Company Law Directive is to establish the rules concerning the statutory audit of annual and consolidated accounts. This revised Eighth Company Law Directive extends the scope of application of existing EU legislation in the audit field by mentioning more clearly the duties of statutory auditors, the criteria for their independence, and professional ethics. The Directive does so through the introduction of new requirements for providing external quality assurance by adopting a better public oversight over audit professionals and stimulating cooperation among various oversight bodies in the European context. In Chapter X, Article 4 states that each public interest entity shall have an AC. An AC should be composed of non-executive members of the administrative body and/or members of the supervisory body of the audited entity and/or members appointed by the general meeting of shareholders of the audited entity with at least one member as a financial or accounting expert. A major responsibility

\footnotetext{
6 We use the term "board of directors" when referring to the academic literature on corporate governance as most published research on the topic deals with the unitary system of corporate governance. When we refer to the Polish corporate governance system, the term "supervisory board" is used.
} 
of the audit committee is to ensure that financial statements are consistent with international accounting standards and that their audit is conducted following international auditing standards. Moreover, the statutory auditor is to report to the AC on key matters that arise from the statutory audit, and specifically on material weaknesses in internal control related to the financial reporting process.

We draw our data from the Warsaw Stock Exchange (WSE). In 2009, ACs became mandatory due to their inclusion in the new legislation on auditing (Journal of Laws, 2009). The new regulation imposes the formation of an AC; however, this requirement depends on the size of the SB. The 2009 regulation states that companies with more than five members on the SB are required to have an AC; however, companies with five or fewer members on the SB can form but are not required to form an AC. Therefore, this new regulation has resulted in various reactions on the side of companies. First, companies with five or fewer members on the SB can form an AC or they can decide not to form an AC. At the same time, companies with an SB with more than five members can decrease the number of members to five so as to avoid the need to form an AC or they must form an AC. This article investigates the determinants of AC formation and compares the role of potential determinants of AC formation before and after the regulation was introduced.

Companies' reaction to the introduction of the new regulation gives rise to the question of which corporate governance characteristics and internal factors determine AC formation in a semi-mandatory setting. To answer our research question, we examined data for companies listed on the WSE in 2008, 2010, and 2015. In 2009, a new regulation was introduced to regulate the existence of ACs in Polish-listed companies. Therefore, we analyzed data for 2008 and 2010. Moreover, we also analyzed data for 2015 to check for any experience-related changes. The empirical methodology was based on logistic regressions.

The results illustrated that - contrary to the studies of companies operating in the Anglo-Saxon environment - the presence of independent board members with accounting and finance experts decreases the likelihood of AC formation. When it comes to capital structure, we observed that after the implementation of the EU directive, companies with foreign ownership are more likely to have an AC. However, we also noticed that recent managerial ownership may also be an important factor in the AC formation decision. Furthermore, in 2008 family firms were less likely to form an AC while larger companies with bigger SBs were more likely to form an AC. However, we did not observe this effect for 2010 and 2015. The effects were highly statistically and economically significant. Moreover, we also observed that the presence of other board 
committees increased the likelihood of AC formation. Our results were robust in relation to other specifications and regulation changes.

This article intends to contribute to two streams of literature. ${ }^{7}$ First, the research seeks to provide insights into why some companies decide to form an $\mathrm{AC}$, and why other reject the concept. To that end, we scrutinize the reactions of publicly listed companies to new regulations. We identify which firm characteristics influence firms' abilities to adapt more quickly to new regulations, which is important from the corporate governance perspective. Recent studies show that the formation of AC has a positive impact on the quality of financial reporting, which is indicated by low earnings management (Putri and Prasetyo, 2020; Mardjono et al., 2020) and the quality of annual financial statements data (Omer et al., 2020). Therefore, it is extremely important to expand the literature on firms' motivations for forming AC. This article extends our knowledge about determinants of AC formation by drawing attention to other important factors that influence companies' decisions to form an AC.

Second, to date, most studies dealing with AC have been conducted predominantly in the United States and the United Kingdom. It is not surprising that many authors call for additional research outside the Anglo-Saxon world (e.g. Bédard and Gendron, 2010; Zhou et al., 2018). This article can be considered a direct response to these calls as we study ACs in the European economy. Moreover, this article adds to our understanding of the divergent practices related to ACs across European countries, so this study fills the gap in the literature by providing new information and evidence from the unexplored European context (Dwekat et al., 2020).

The remainder of the article is organized as follows. After the introduction, we present the context of the study and describe the Polish corporate governance bundle. The following section presents theoretical background and reviews literature, leading to the development of the hypotheses. Next, we provide information on the empirical design of the study, followed by a reporting of results. Then, we show robustness checks of our main conclusions. Finally, the last section discusses the article's findings, implications, limitations, and recommendations for future research.

7 We use citation count regression (Staszkiewicz, 2019) for a research gap verification. 


\section{Study Context: The Polish Governance Bundle}

Poland is a country with dependent boards (Mateescu, 2015) and a contemporary corporate governance system that can be characterized as an "insider" model of corporate governance. In this system, owners monitor, oversee, and control companies from within. Consequently, owners frequently take large ownership stakes. Ownership and control are in the hands of families and business groups (Dobija, 2011).

The internal corporate governance mechanisms in Poland rely on the board and its committees. The board is organized following a two-tiered model consisting of a management board (executive directors) and an SB (non-executive directors). The management board is responsible for monitoring, controlling, providing information, counseling, and ensuring compliance with applicable laws and regulations. The SB is in charge of monitoring the company's and management board's activities (Słomka-Gołebiowska and Urbanek, 2016). In general, supervisory boards are much smaller than the boards in the one-tier governance model. The average size of an SB in listed companies in Poland is six members (Bohdanowicz, 2015). An audit, remuneration, and nomination committees are appointed to facilitate the supervisory board's monitoring role. Therefore, we may say that the committee's establishment has two main goals. First, it serves to improve the effectiveness of an SB. Second, the recommendations of the relevant committee make SB's decisions more independent from the management board and shareholders (Wieczorek, 2012). In contrast to other committees, ACs became mandatory and were stipulated by the Polish Auditing Act of 2009 (Journal of Laws, 2009). The establishment and operation of ACs on supervisory boards were now formally required for companies with SB's larger than five members, while AC responsibilities became mandatory. However, due to the Polish Auditing Act of 2009 (Journal of Laws, 2009), in the absence of an AC, in order to perform the obligations of the AC specified in this Act, its functions may be entrusted to the SB or to any other supervisory body or public interest entity. The Polish Auditing Act of 2009 (Journal of Laws, 2009) defines the tasks of the audit committee:

- monitoring of the financial reporting process;

- monitoring of the effectiveness of the internal control system, risk management, and internal audit systems;

- monitoring of the performance of financial auditing activities, in particular by audit firms;

- controlling and monitoring of the independence of the statutory auditor and the audit firm, especially if the audit firm provides to the public interest entity services other than auditing. 
Moreover, according to the regulation, the AC must consist of at least three members, including at least one member complying with the conditions of independence and having qualifications in accounting or auditing. There are many advantages to forming an AC. Recent research suggests that effective ACs provide better audit quality (Ali et al., 2018) as the desired effect of introducing ACs is to increase the quality of financial reports and, therefore, maintain investor confidence. Research so far shows that the investment level is higher in firms with good corporate governance practices (Shahid and Abbas, 2019). From the organization's perspective, the only disadvantage is their relatively high cost of AC (Pincus et al., 1989).

Since the new regulation allowed an option, companies could react in different ways. Therefore, when the new regulation came into force, companies could react differently, which depended on the size of the SB. Companies with more than five members on the $\mathrm{SB}$ were required to have an $\mathrm{AC}$, but those with five or fewer members on the $\mathrm{SB}$ could form an AC but were not required to do so. Figure 1 explains the possible actions taken by companies.

Figure 1. The reaction of Polish companies to the regulation changes

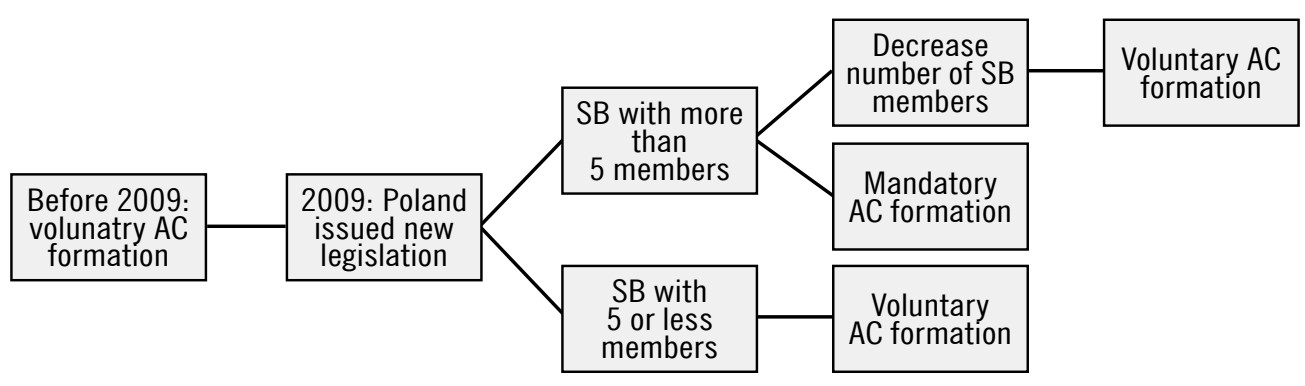

Source: own elaboration.

The reaction of companies listed on the WSE to the new regulation was twofold. One group of companies decided to form an AC (almost 19\% of all companies), according to the existing laws. However, a larger group decided to take advantage of the exemption and not form an AC (almost 50\% of all companies). Anecdotal evidence exists of cases in which companies preferred to reduce the number of members of their SB to avoid the need to form an AC (almost 8\% of companies). The different reactions of listed companies to the introduction of the obligation to form audit committees allowed us to conclude ex-post that the regulatory risk associated with the introduction of this obligation did materialize: the legislator failed to introduce this institution uniformly in all of the entities (Adamska et al., 2017). 


\section{Figure 2. Audit committee regulation changes in Poland and the sample construction}

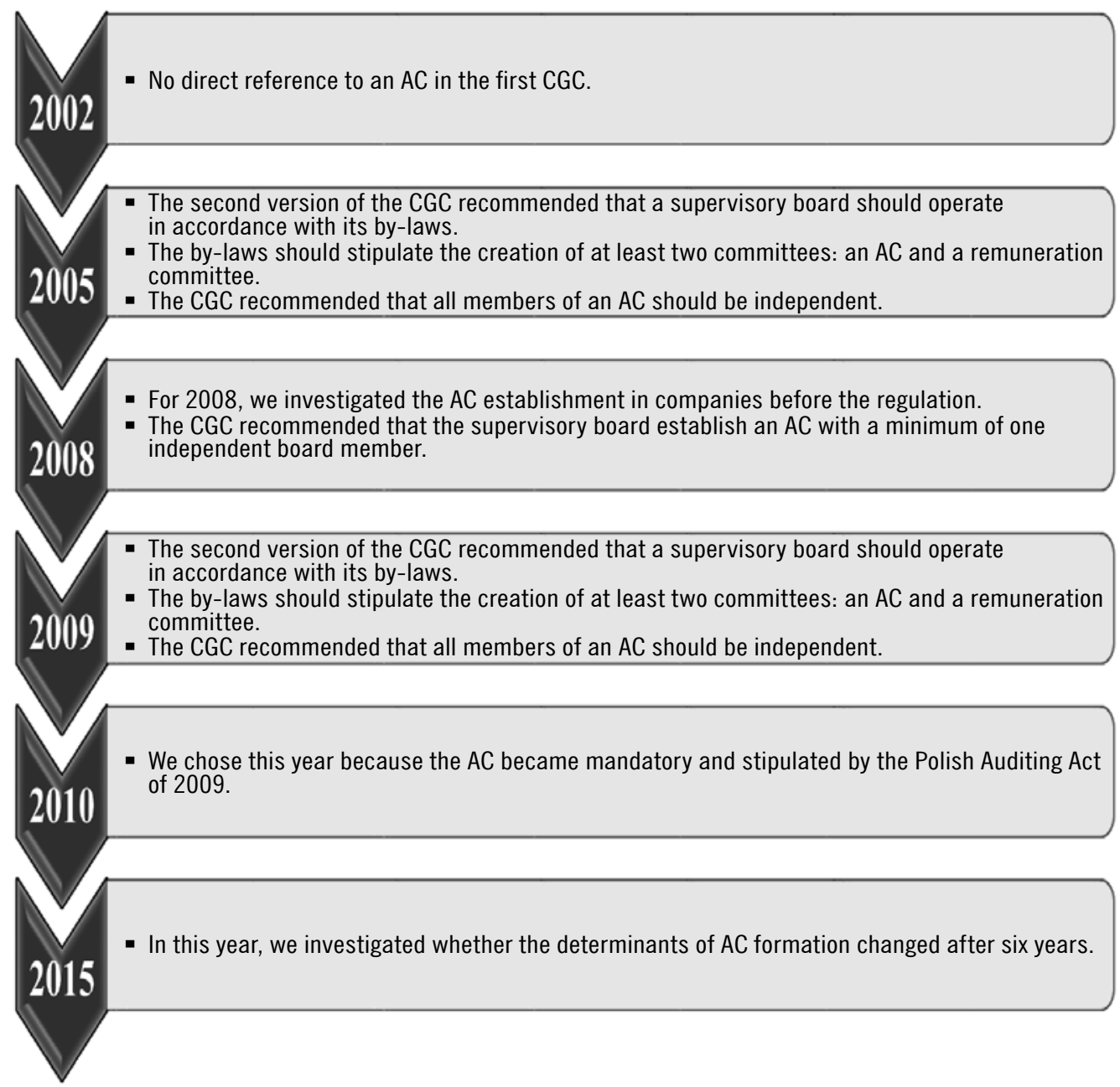

Note: AC - audit committee; CGC - corporate governance code.

Source: own elaboration.

The following Figure 2 illustrates the changes in the AC regulation and explains the rationale for the construction of our sample. We selected 2008, 2010, and 2015 for the analysis. We assumed that in $2008 \mathrm{AC}$ formation was voluntary, as there was no legislation regulating the formation of ACs. We analyzed data for 2010 to find changes after the introduction of a new regulation. Furthermore, we analyzed data for 2015 to find changes. We did not analyze years later than 2015 due to the 2017 regulatory changes. The new Act of May 11, 2017, on Statutory Auditors, Audit Firms, and Public Oversight, 
Chapter 8, Article 128 specifies that the performance of an AC's function can be entrusted to the SB (Journal of Laws, 2017) only in those public interest entities that do not exceed at least two of the following three amounts:

- PLN 17,000,000 in the case of the sum of balance sheet assets as at the end of the financial year;

- PLN 34,000,000 in the case of the net revenue from sales of goods and products for the financial year;

- 50 employees in the case of the average annual employment expressed in fulltime jobs.

\section{Theory and Hypotheses Development}

\section{Theoretical Perspectives}

In theory, companies should benefit from the presence of an AC. The agency theory (AT) perspective suggests that ensuring the presence of an AC increases its monitoring role in protecting shareholders' interests from the management's self-interests (Bradbury, 1990; Menon and Williams, 1994; Piot, 2004). From the AT perspective, the establishment of ACs is regarded as a reaction to information asymmetry between company owners and management (Köhler, 2005). As the board of directors is charged with safeguarding the interests of shareholders (Fama and Jensen, 1983), an AC will be employed in high-agency cost situations to improve the quality of information flows between the principal and the agent (Pincus et al., 1989), therefore reducing agency costs.

\section{Hypothesis Development}

The two main categories of determinants influencing the establishment of an AC that emerged from the literature review include (1) board compositional features and (2) company-specific determinants.

\section{Board Compositional Features and AC Formation}

The board of directors is viewed as one of the most important internal corporate governance mechanisms for reducing agency problems (Fama and Jensen, 1983; Kroll et al., 2008; Belkhir, 2009). In our research, we will focus on the following board composition characteristics: the experience and expertise of board members, board members' independence, and gender diversity. Moreover, we investigated whether the existence of other ACs positively influences AC formation. 


\section{Board Members' Experience and Expertise}

The size of the board of directors can positively affect the creation of an AC as a large board allows for the inclusion of members with different backgrounds who represent various firm stakeholders, along with broad knowledge and experience. Beasley and Salterio (2001) affirm that as the board size increases, what also increases is a firm's ability to appoint more independent directors with relevant financial reporting, AC knowledge, and experience. To exercise its monitoring function, the board needs an appropriate mix of experience and knowledge (Hillman and Dalziel, 2003). Therefore, if members hold different experience and knowledge levels, they may want to increase the monitoring process by the establishment of an AC.

Beasley's and Salterio's (2001) study illustrates that firms voluntarily create audit committees composed of outside members with a breadth of relevant financial reporting and $\mathrm{AC}$ knowledge and experience. Consequently, we argued that the larger the number of experienced directors with accounting and/or financial knowledge on the board, the more likely the firm will be to form an AC. This prediction results in our first hypothesis:

H1a: The greater the proportion of experienced members on the board, the greater the likelihood of the existence of an AC.

H1b: The greater the proportion of expert members on the board, the greater the likelihood of the existence of an AC.

\section{Board Independence}

Independent members are defined as non-management or outside members of the board (Johnson et al., 1996) chosen in the interest of the shareholders (Salloum et al., 2015). The SB also contains inside members who have inside information. Therefore, the domination of inside members may lead to a lack of management monitoring and increase the number of agency problems (Nicholson and Kiel, 2007). The AC should independently complete its responsibilities regarding the efficiency of auditing. Consequently, some independent members may set out to form ACs with the aim of enhancing corporate governance (Salloum et al., 2015).

Prior studies suggest that boards with a higher proportion of independent directors are more effective at monitoring managers (Huang et al., 2009). Such boards are more likely to remove a poorly performing manager and select a specialist Big Four auditor (Beasley and Petroni, 2001). A more independent board is more likely to adopt a gover- 
nance committee for overwatch (Huang et al., 2009) as independent members have incentives to reduce their legal liability by forming an AC (Collier, 1993). Moreover, board independence and the existence of an AC both positively correlate with financial reporting quality (Afify, 2009).

Bradbury (1990) considers independent directors to have an incentive to ensure the effective running of the company. Studies reveal that board independence has a positive relationship with the AC formation (Pincus et al., 1989; Zhou et al., 2018; Abdeljawad et al., 2020). Consequently, we argue that the larger the proportion of independent members on the board, the more likely a firm to form an AC. This prediction leads us to our next hypothesis:

H2: The greater the proportion of independent members on the board, the greater the likelihood of the existence of an AC.

\section{Women Participation on Boards}

Women are expected to enrich leadership style, deliver new values, and as a result, contribute to a firm's better performance and increase in value (Aluchna, 2013). Moreover, women are considered to be more independent decision-makers, more risk-averse, and less tolerant of unethical behavior (Srinidhi et al., 2011). This could lead to better monitoring quality and more informative financial data.

Post and Byron (2015) document that female board representation is positively related to the SB's monitoring function. Adams et al. (2011) report that women think independently and are not influenced by "old boy networks." These tendencies should improve company monitoring, especially in companies with corporate governance. Consequently, we argue that the greater the proportion of women on an SB, the more likely a WSE-listed firm will form an AC. This prediction leads us to test the following hypothesis:

H3: The greater the proportion of women on the board, the greater the likelihood of the existence of an AC.

\section{Experience with Other Committees' Formation}

Boards may freely select their corporate governance structure from a range of possibilities. Possible decisions that relate to board structure include forming various subcommittees. Carson (2002) and Spira and Bender (2004) strongly recommend the establishment of board subcommittees as a potential mechanism for improving cor- 
porate governance. Among other things, the subcommittees may refer to remuneration, strategy, or nomination issues.

Premuroso and Bhattacharya (2007) find that performance ratios (i.e. return on assets) appear to be associated with firms' decisions to form board-level technology committees. Moreover, Huang et al. (2009) find that having a governance committee constrains managerial opportunism by reducing aggressive financial reporting.

We assume that a positive experience with other board committees may make a firm more willing to form an AC. Consequently, we argue that if a company already has experience with other committees, it is more likely to form an AC. This prediction leads us to test the following hypothesis:

H4: There is a positive association between the existence of other committees and the likelihood of AC existence.

\section{Company-Specific Determinants of AC Formation}

The literature finds that substantial shareholders (i.e. individual and institutional investors who hold a substantial stake in a firm) are related to the existence of ACs (Bradbury, 1990). Thus, we consider three types of possible ownership: managerial, family, and foreign ownership. Moreover, Abdeljawad et al. (2020) find that ownership concentration enhances the chance of AC formation.

\section{Managerial Ownership}

Auditing Committees are some of the most important components of corporate governance because they explicitly separate management and monitoring duties (Köhler, 2005). From an AT perspective, the need to implement monitoring mechanisms stems from the divergence of interests between managers and stockholders. The intensity of this conflict is inversely related to the higher level of managerial ownership concentration (Jensen and Meckling, 1976).

According to AT, the higher the level of managerial ownership, the lower the probability that managers will manipulate accounting numbers to satisfy their interests. Here, AT is the theoretical framework of ACs generally applied in an Anglo-Saxon setting because ACs primarily are an institution employed to align the interests of owners and management (Köhler, 2005). Moreover, the concentration of ownership by managers may increase the supervisory powers of shareholders, making the presence of an AC unnecessary (Piot, 2004). 
Prior empirical studies confirm the theoretical assumptions and provide evidence of a negative relationship between managerial ownership and AC formation (e.g. Deli and Gillan, 2000; Piot, 2004). The previous discussion suggests that the need for external monitoring will be lower with the increase of management ownership. Therefore, there will be a smaller likelihood of AC formation. Consequently, we develop the fifth hypothesis:

H5: The greater the proportion of managerial ownership, the lower the likelihood of the existence of an AC.

\section{Family Ownership}

Auditing Committees can be viewed as a monitoring mechanism that will be formed voluntarily in high agency cost situations to improve the quality of information flow between the principal and agents (Bradbury, 1990). The higher the owner-manager ownership stake in a firm, the lesser the divergence of interests, thus the less likely need of monitoring (Menon and Williams, 1994). Thus, the AT predicts the establishment of ACs as a means of attenuating agency costs through its monitoring role (Menon and Williams, 1994).

Family ownership means that the founders or their immediate family hold a percentage of shares significant enough to account for the largest shareholding (Chau and Gray, 2002; Chau and Leung, 2006). These owners may influence most management decisions. Similar to the case of managers as owners, the concentration of family ownership may decrease the supervisory powers of other shareholders, thus decreasing the likeliness of an AC's existence. Accordingly, we expect a family firm to less likely form an AC. Therefore, we propose the following hypothesis:

H6: There is a negative association between family ownership and the likelihood of AC existence.

\section{Foreign Ownership}

Foreign ownership acts as a monitoring mechanism for management's behavior and improves corporate governance, especially in emerging markets (Bekaert and Harvey, 2002). Local investors have an information advantage relative to their foreign investors, who are geographically separated from the company, due to relatively easier access to firm-relevant information (Coval and Moskowitz, 2001). The supervisory board's tasks concerning financial accounting and other shareholder-oriented company information should be performed in ACs (Köhler, 2005), especially to reduce agency conflicts between local investors and foreign investors (Bushman and Smith, 2003). 
Mangena and Tauringana (2007) document a positive relationship between the percentage of shares held by foreign shareholders and the presence of ACs. Moreover, if effective corporate governance practices are of value to large investors, then we would expect to see the adoption of best practices even in the absence of mandated requirements (Carson, 2002). Small shareholders may not have sufficient incentives to justify additional expenditures on the monitoring of management (Shleifer and Vishny, 1986). Therefore, the presence of an AC may provide the audit process with more credibility to large investors (Carson, 2002). Thus, we expect that the higher the level of foreign ownership, the more likely a firm listed on the WSE will be to form an AC. As such, we posit the following:

H7: The greater the proportion of foreign ownership, the greater the likelihood of the existence of an AC.

In the following section, we will describe our sample used for empirical testing of the above hypotheses.

\section{Methods}

\section{Sample Construction}

To test SBs' role and companies' compositional characteristics in AC creation, we evaluated companies listed on the WSE. Our samples consisted of the population of Polish nonfinancial firms listed on the WSE in 2008-2015 that represented the following industry sectors: merchandising (ca. 34\%), service (ca. 26\%), and manufacturing (ca. 40\%). In 2008, AC formation was voluntary, so we used the sample of all nonfinancial Polish companies listed on the WSE in that year. In 2010 and 2015, companies could choose to decrease the number of members on the SB or form an AC. Therefore, for 2010 and 2015, we only took companies with boards consisting of fewer than six members. Table 1 details the case selection process.

For this study, we collected information related to SBs and consolidated financial statement data from the Notoria Service, a WSE-listed company that sells financial information. Missing information was hand-collected from other sites (e.g. LinkedIn).

The data were collected for 2008, 2010, and 2015. It was important to collect data for 2008 to investigate AC establishment in companies before the regulation. We assumed that in $2008 \mathrm{AC}$ formation was voluntary, as there was no legislation regulating the formation of ACs. Relevant regulation was introduced a year later, so we investigated 
which companies consciously decided to form an AC and which decided to reduce the number of SB members. Data for 2010 were relevant because ACs became voluntary only for companies with five or fewer SB members, as stipulated by the Polish Auditing Act of 2009, when Poland issued new legislation regulating the role of ACs (Journal of Laws, 2009). Moreover, we chose data for 2015 to compare whether determinants of AC formation changed after six years. Overall, we analyzed data for 231 companies in 2015, 147 companies in 2010, and 142 companies in 2008.

\section{Table 1. Sample selection}

\begin{tabular}{|l|c|c|c|}
\hline \multicolumn{1}{|r|}{} & \multicolumn{3}{|c|}{ Time-periods } \\
\hline Companies: & $\mathbf{2 0 0 8}$ & $\mathbf{2 0 1 0}^{\mathbf{*}}$ & $\mathbf{2 0 1 5}^{* *}$ \\
\hline - An AC has been formed & 70 & 26 & 27 \\
\hline - No AC has been formed & 161 & 121 & 115 \\
\hline TOTAL SAMPLE & $\mathbf{2 3 1}$ & $\mathbf{1 4 7}$ & $\mathbf{1 4 2}$ \\
\hline
\end{tabular}

*,** The number of companies with mandatory AC formation are excluded.

Source: own elaboration.

\section{Dependent Variable}

The dependent variable tracked whether a company formed AC at the end of the financial year. This indicator variable was equal to 1 if an AC was established and 0 if otherwise. This variable was used in prior research on AC formation (Bédard and Gendron, 2010; Zaman and Valentinčič, 2011).

\section{Independent Variables}

The hypotheses considered board and firm characteristics. More specifically, to verify H1, we used the percentage of board members with experience (EXP) and the percentage of board members with finance and accounting expertise (EXT). To verify H2, we applied the percentage of independent board members (INT). To verify H3, we employed the percentage of women on the SB (WOB). In order to be classified as an experienced member, a person needed to have documented professional experience. To be considered an expert, a person needed to have proven accounting or financial knowledge. To be considered an independent member, a person had to be independent from the management board and meet the criteria of independence listed in the Polish Auditing Act of 2009. The criteria regarding women as board members were gender-dependent. 
The demographic data of the board members in our sample companies were taken from biographical notes provided by the Notoria Service and the Internet (e.g. LinkedIn). To verify H4, we used an additional governance variable: the presence of subcommittees (SC).

A set of variables related to the ownership structure of a firm were included in the analyses. To verify H5, we applied the managerial ownership variable (MANOWN). The variable MANOWN represented the proportion of shares held by management at the end of the year. To verify H6, we employed family the ownership variable (FAMOWN), which was a dummy variable of 1 when the majority of shares was held by a family at the end of the year and 0 if otherwise. Following Chau and Leung (2006), we assumed that at the high level of family shareholding (more than 25\%), the family owners' "voice" dominates. To verify H6, we used the foreign ownership variable (FRGOWN). The variable FRGOWN represented the proportion of shares held by foreign investors at the end of the year.

The data on the ownership structure were collected from the Notoria Service. Consistent with prior studies, we included a set of control variables. Following Zaman and Valentinčič (2011), we utilized the board size (BSIZE) as our first control variable measured counted from the total number of board members in 2008. We did not control for board size in 2010 and 2015 because the state legislation required AC formation to depend on the number of SB members. Moreover, we used the frequency of board meetings (MEET), measured by the number of meetings per year (Mangena and Tauringana, 2008). We controlled for the type of auditor (BIG4; Zaman and Valentinčič, 2011), included leverage (LEV; Piot, 2004; Zaman and Valentinčič, 2011; Bradbury et al., 2019), and measured firm size (FSIZE), the latter by the natural logarithm of a firm's assets (Zaman and Valentinčič, 2011; Bradbury et al., 2019).

Following empirical literature, we controlled for the time a firm was listed, as the existing research shows that older companies are more willing to operate in accordance with the law (LIST; Kaczmarek et al., 2012). Furthermore, in our regression models, we use the market growth potential ratio (GROWTH), defined as the ratio of a firm's market and book value of equity (Deli and Gillan, 2000). We assumed that ACs will be able to evaluate managers based on future growth options rather than on present performance.

We controlled for manufacturing (SECMAN) and merchandising sectors (SECMER) as we assumed that the tendency to form ACs would be higher in some sectors over other. Moreover, we controlled for losses in the previous financial year (LOSS). We 
¿ NOTORIAL SERVICE/Annual Management, Supervisory Boards Reports/

Web pages/Linkedln

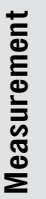
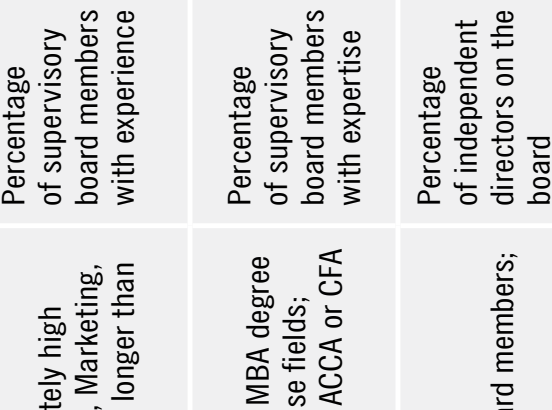

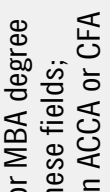

نั

훙 흔은

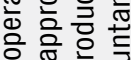

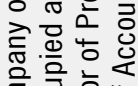

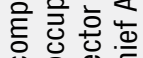

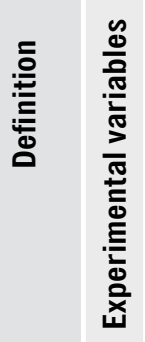

U.

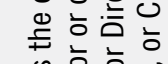

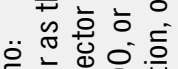

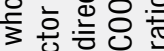

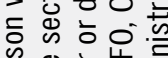

क⿺辶े

๙

은

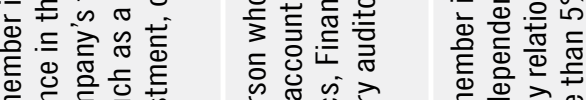

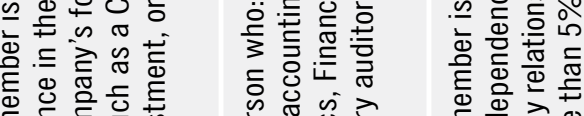

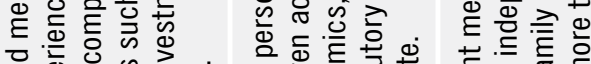

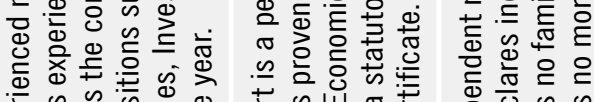

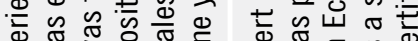

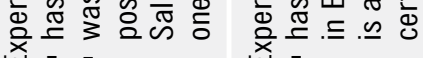
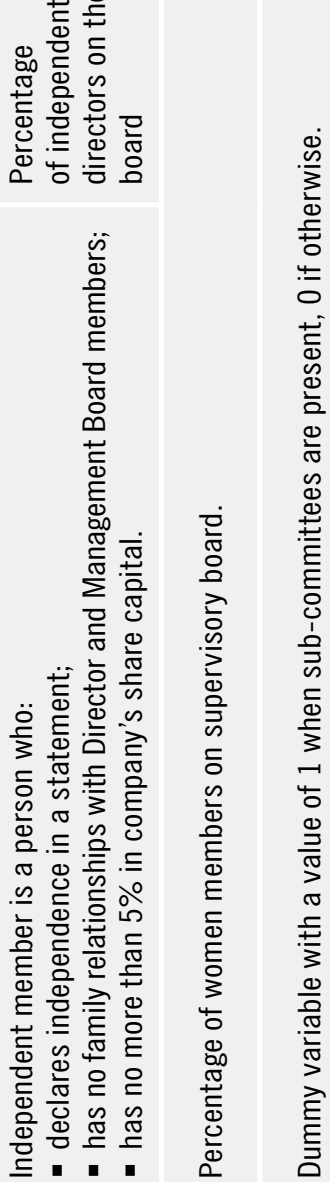

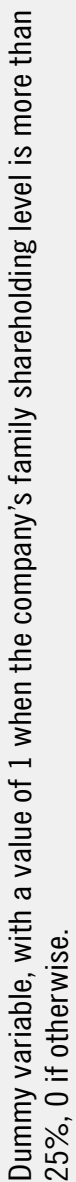

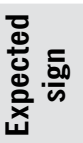

侖

要 曹

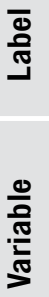

妾

离

$\geqq \stackrel{\wp}{3}$

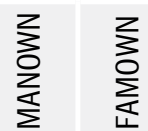

흘

N

$\frac{0}{\frac{1}{0}}$

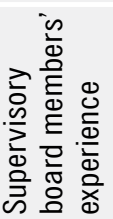

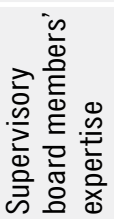

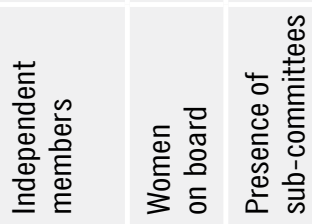

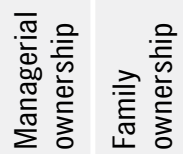


NOTORIAL SERVICE/Annual Management, Supervisory Boards Reports/

Web pages/Linkedln

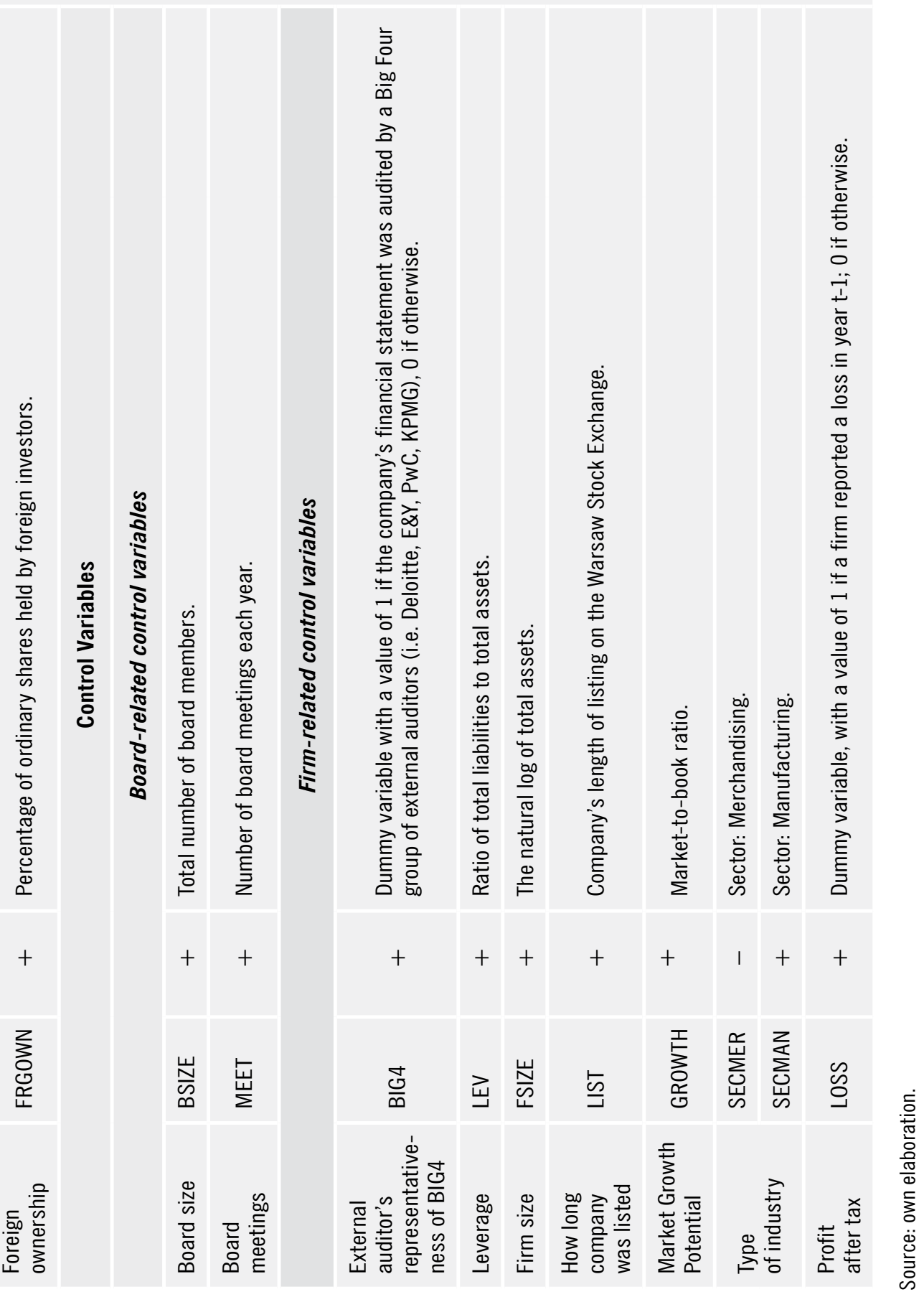


expected that if a company reported a loss in year $t-1$, then in year $t$ it will be more willing to form an AC. Table 2 summarizes each of the above aspects, provides information about supporting literature, and indicates the expected signs of relationships.

\section{Methodology and Statistical Models}

The dependent variable was an indicator variable, set to 1 if the firm had an AC, and 0 if otherwise, while independent variables were either continuous or dichotomous. For our analyses, we used logistic regression due to the dichotomous nature of the dependent variable and following Bradbury (1990), Beasley and Salterio (2001), Carson (2002), Piot (2004), Chau and Leung (2006), Chen et al. (2009), Zaman and Valentinčič (2011), and Hassan and Hijazi (2015). Moreover, these authors use a similar approach to determine factors of AC formation. We tested our hypotheses using the following logit model:

$$
\begin{aligned}
& \ln \left(\frac{p_{A C}}{1-p_{A C}}\right)=\beta_{0}+\beta_{1} \text { Variable from the hypothesis }{ }_{j t}+\beta_{2} \text { BSIZE }_{j t}{ }^{*}+\beta_{3} \text { MEET }_{j t}+\beta_{4} \text { BIG }_{j t} \\
& +\beta_{5} \mathrm{LEV}_{\mathrm{jt}}+\beta_{6} \text { FSIZE }_{-} \mathrm{LN}_{\mathrm{jt}}+\beta_{7} \mathrm{GROWTH}_{\mathrm{jt}}+\beta_{8} \mathrm{LIST}_{\mathrm{jt}}+\beta_{9} \text { SECMER }_{\mathrm{jt}} \\
& +\beta_{10} \operatorname{SECMAN}_{\mathrm{jt}}+\beta_{11} \text { LOSS }_{\mathrm{jt}-1}+\mathbf{r}_{\mathrm{jt}}
\end{aligned}
$$

* As explained above, due to the fact, that for the years 2010 and 2015 only firms with less than 6 members in the board were taken into account, there was almost no variation in board sizes in the analysed population in these years, therefore BSIZE variable is included only in the 2008 models.

in which

$\mathrm{p}_{\mathrm{AC}}=$ probability that the firm has an $\mathrm{AC}$,

$\beta_{0}=$ intercept term,

$\beta_{1}=$ coefficient for the variable from a given hypothesis (H1-H7),

$\beta_{2}-\beta_{11}=$ coefficients for the control variables,

$\mathrm{j}=$ firm's identifier,

$\mathrm{t}=$ time as year,

$\mathrm{r}_{\mathrm{jt}}=$ error term.

In this study, we intended to examine the association between firms' characteristics and $\mathrm{AC}$ existence in the following three points in time: the year before the new Polish Auditing Act of 2009 (Journal of Laws, 2009), one year after the regulation came into force (2010), and six years later (2015). The populations included in the analyses were different in each year, and the differences in their composition stemmed not from missing data but from other population definitions; that is, we took into account all the firms listed on the WSE that had a choice on whether to create an AC. Therefore, we did not scrutinize our data as a panel but instead built separate models for each year. 


\section{Summary Statistics}

Tables 3 and 4 present the summary statistics for the variables used in the regression for the companies that did and did not form an AC, respectively. The differences between the groups were tested using an independent sample t-test for the variables measured on a ratio scale with distributions close to normal, Mann-Whitney U for non-normally distributed variables, and a chi-squared test for the dummy variables.

Table 3. Dummy variables' statistics

\begin{tabular}{|c|c|c|c|c|c|}
\hline Year & Variable & $\begin{array}{l}\text { No Audit } \\
\text { Committee }\end{array}$ & $\begin{array}{l}\text { Audit Committee } \\
\text { (AC) exists }\end{array}$ & $\chi^{2}$ & p value \\
\hline \multirow{6}{*}{2008} & \%FAMOWN & 35.4 & 12.9 & 12.15 & $<0.001$ \\
\hline & \%BIG4 & 19.9 & 51.4 & 24.20 & $<0.001$ \\
\hline & $\% S C$ & 5.0 & 70.0 & 111.01 & $<0.001$ \\
\hline & \%LOSS(t-1) & 11.2 & 12.9 & 0.13 & 0.715 \\
\hline & $\%$ SECMER & 30.8 & 38.6 & 1.32 & 0.251 \\
\hline & \%SECMAN & 42.2 & 42.9 & 0.00 & 0.990 \\
\hline \multirow{6}{*}{$\begin{array}{c}2010 \\
(\mathrm{n}=147)\end{array}$} & \%FAMOWN & 39.7 & 26.9 & 1.485 & 0.223 \\
\hline & \%BIG4 & 17.4 & 30.8 & 2.432 & 0.119 \\
\hline & $\% S C$ & 5.8 & 46.2 & 30.989 & $<0.001$ \\
\hline & \%LOSS(t-1) & 24.0 & 15.4 & 0.905 & 0.341 \\
\hline & \%SECMER & 27.3 & 61.5 & 11.308 & 0.001 \\
\hline & \%SECMAN & 42.1 & 23.1 & 3.279 & 0.070 \\
\hline \multirow{6}{*}{$\begin{array}{c}2015 \\
(n=142)\end{array}$} & \%FAMOWN & 37.4 & 44.4 & 0.458 & 0.498 \\
\hline & \%BIG4 & 27.0 & 48.1 & 4.592 & 0.032 \\
\hline & $\% S C$ & 5.2 & 44.4 & 30.397 & $<0.001$ \\
\hline & $\% \operatorname{LOSS}(\mathrm{t}-1)$ & 16.5 & 29.6 & 2.440 & 0.118 \\
\hline & \%SECMER & 31.3 & 29.6 & 0.029 & 0.866 \\
\hline & \%SECMAN & 39.1 & 48.1 & 0.736 & 0.391 \\
\hline
\end{tabular}

Source: own elaboration. 


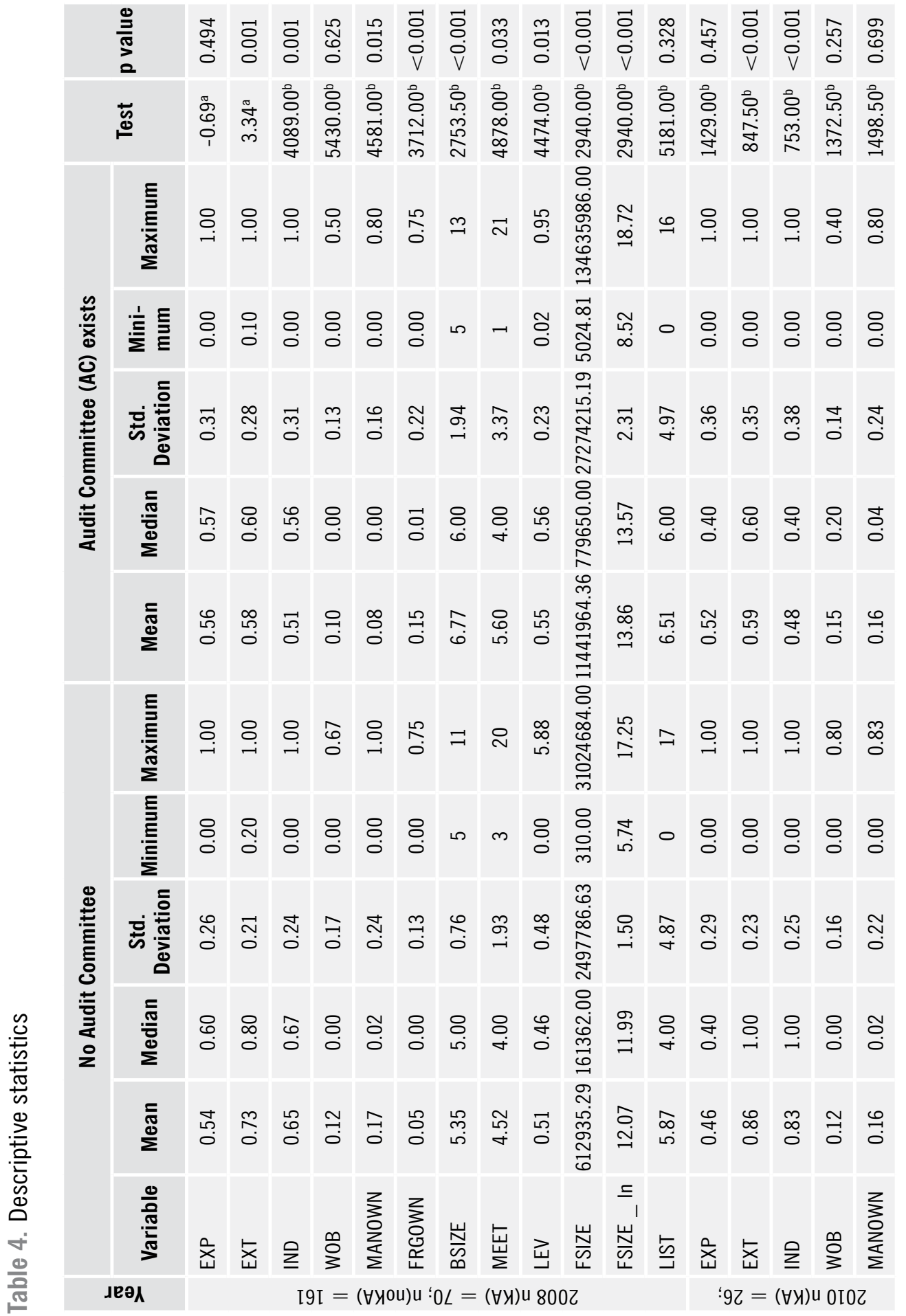




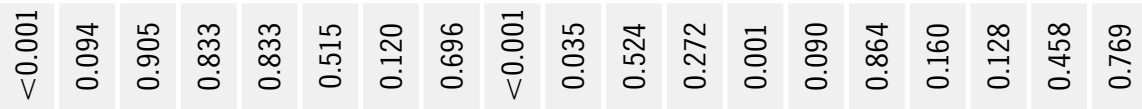

占

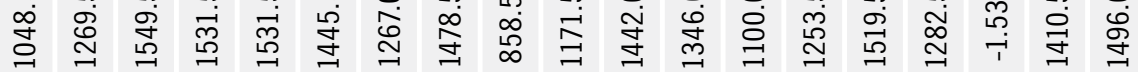

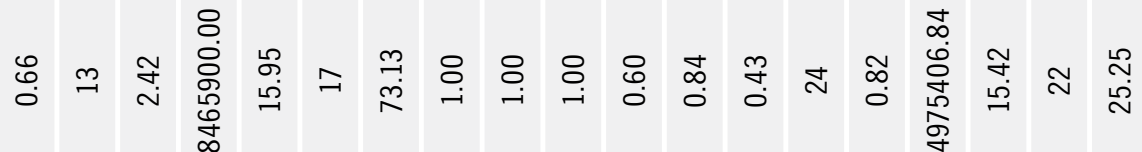

ᄋ

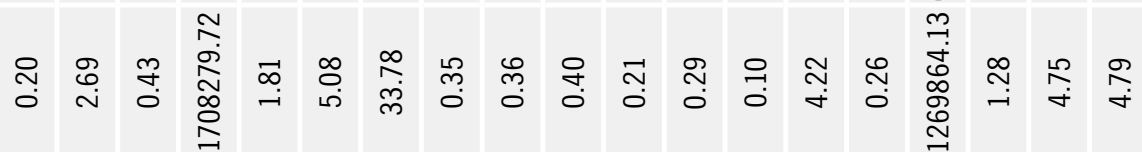

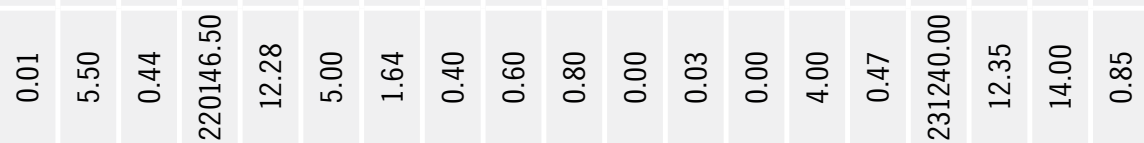

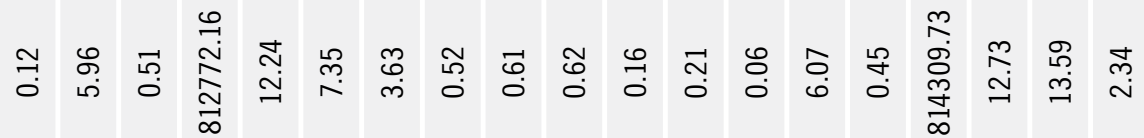

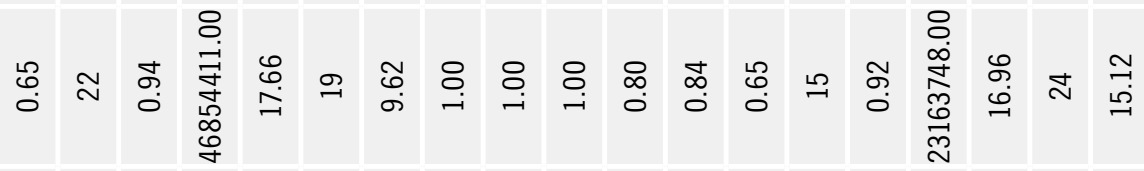

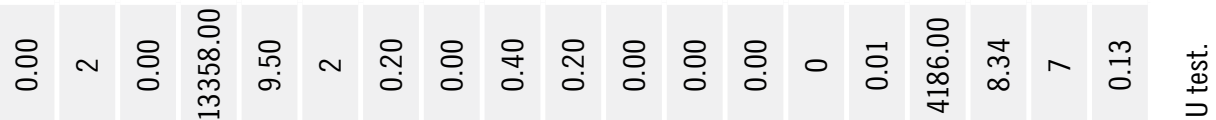

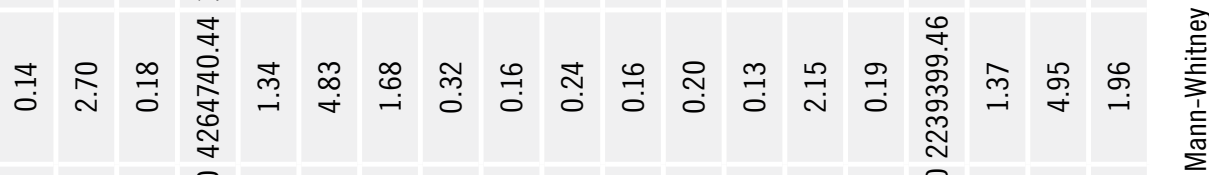

৪

ᄂ

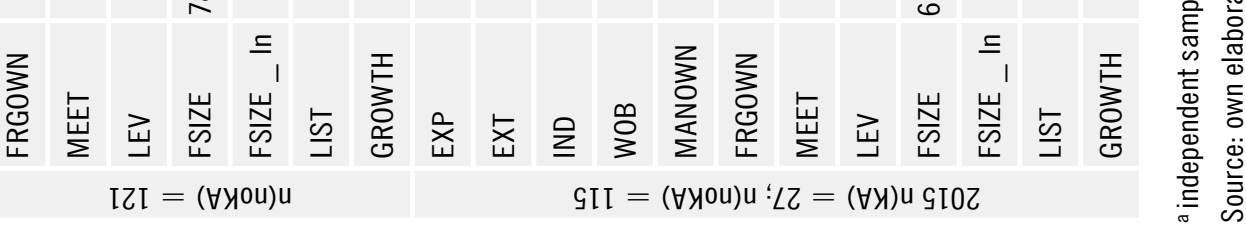


The descriptive statistics results revealed that in 2008 - in companies that formed an AC - there were on average more experienced members, while fewer experts, independent members, and women. In 2010, in companies that formed an AC, there were fewer experts and more experienced and fewer independent members; there were also more women. In 2015, in companies that formed an AC, there were on average more experienced members, fewer experts and independent members, and there were more women. These results confirm the tendencies for 2008, 2010, and 2015. More specifically, companies that did not establish an AC had more experts and independent members.

\section{Correlation Matrix}

Table 5 presents the results of Spearman's correlation testing for multicollinearity.

The correlation between most of the pairs was low, generally below 0.3. None of the correlation coefficients was high enough $(>0.80)$ to cause multicollinearity problems (Archambeault and DeZoort, 2001). Moreover, we assessed multicollinearity by using variance inflation factor (all VIF's were below 2.7).

\section{Multivariate Analyses Results}

This section empirically investigates whether companies were more likely to have an AC in 2008, 2010, and 2015 if on their SB appeared: members with experience or expertise; independent members or women; companies with higher managerial, family, or foreign ownership; subcommittees other than an AC subcommittee (controlling for firm characteristic). Tables 6, 7, and 8 present the logistic regression results for 2008, 2010, and 2015, respectively.

The results document that companies with more members with finance and accounting literacy (EXT) and a higher share of independent members were less likely to have an AC. Moreover, firms with subcommittees other than an AC were more likely to have an AC in 2008, 2010, and 2015. Furthermore, in 2008 and 2010, foreign ownership was statistically significant. Hence, companies with higher foreign ownership were more likely to form an AC. On the other hand, in 2008, family companies were less likely to form an AC.

Our results illustrate that the presence of independent finance and accounting experts among board members reduced the probability of AC existence. Auditing Committees 


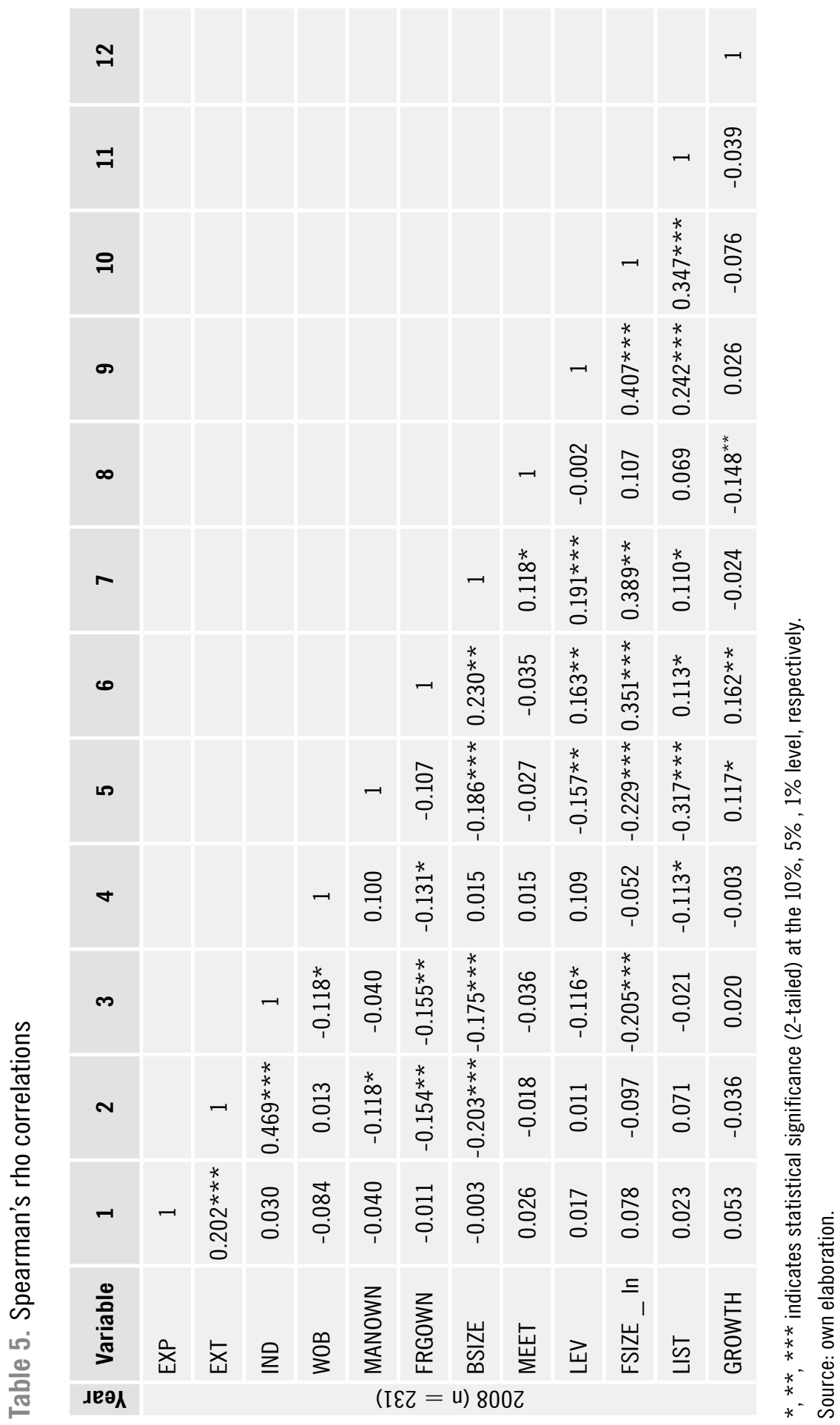




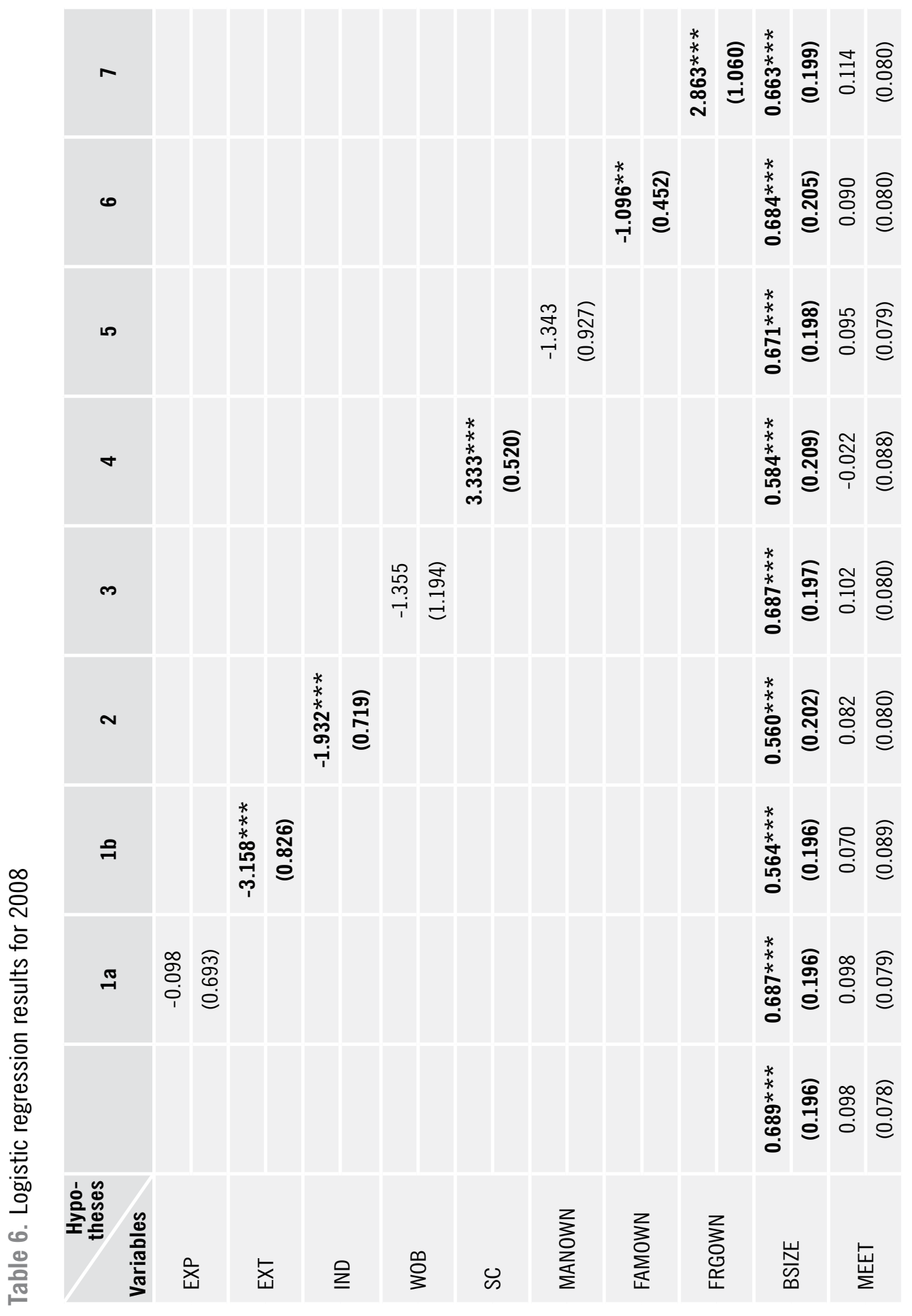




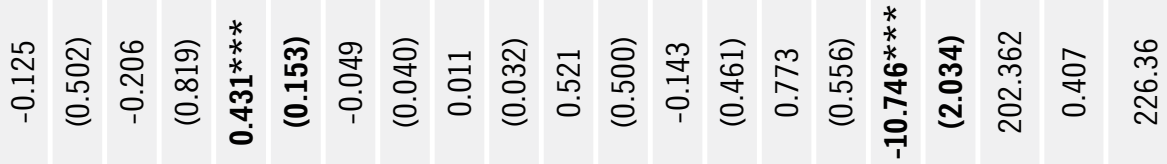

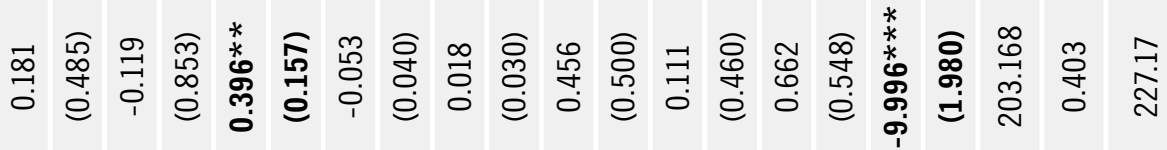

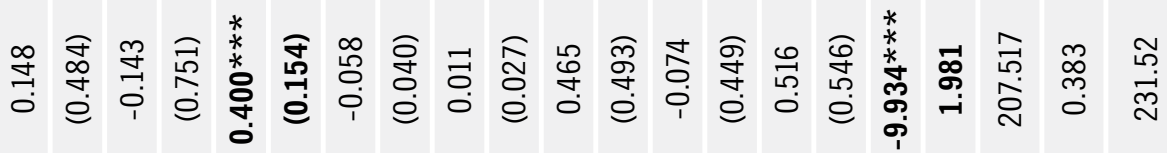

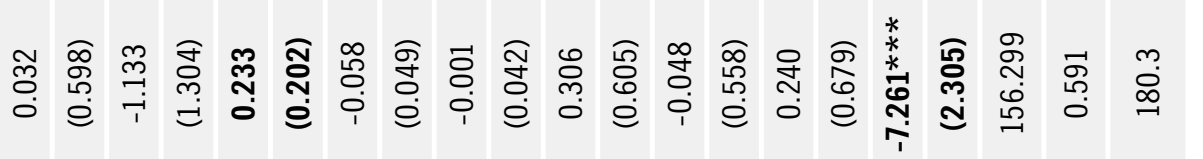

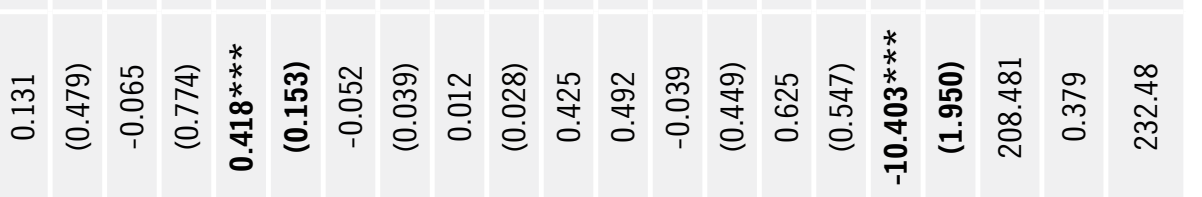

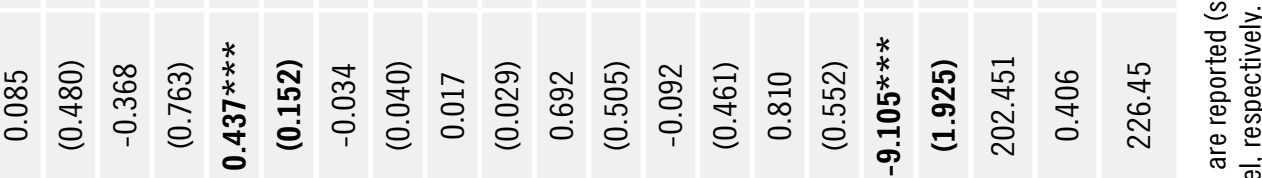

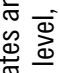

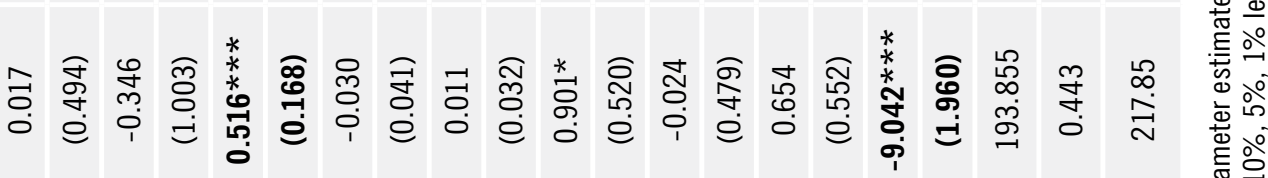

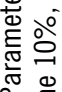

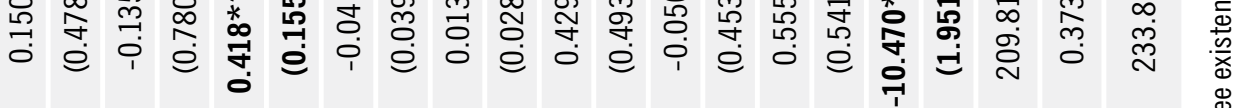

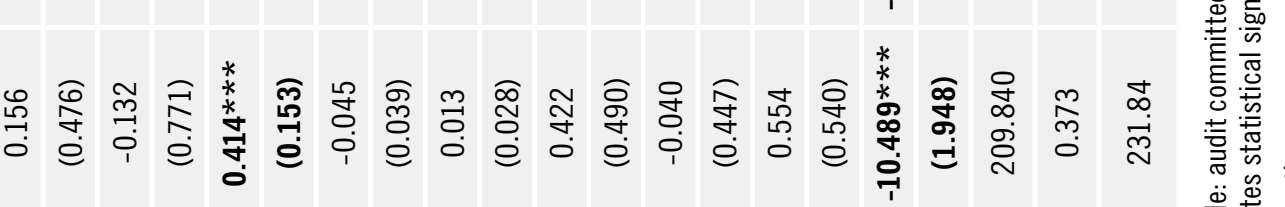

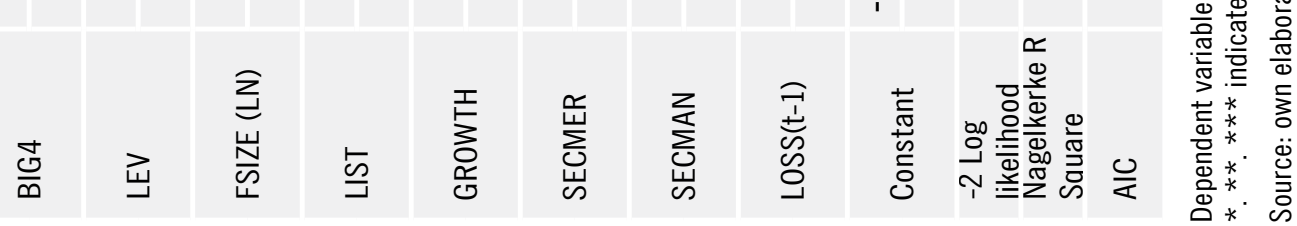




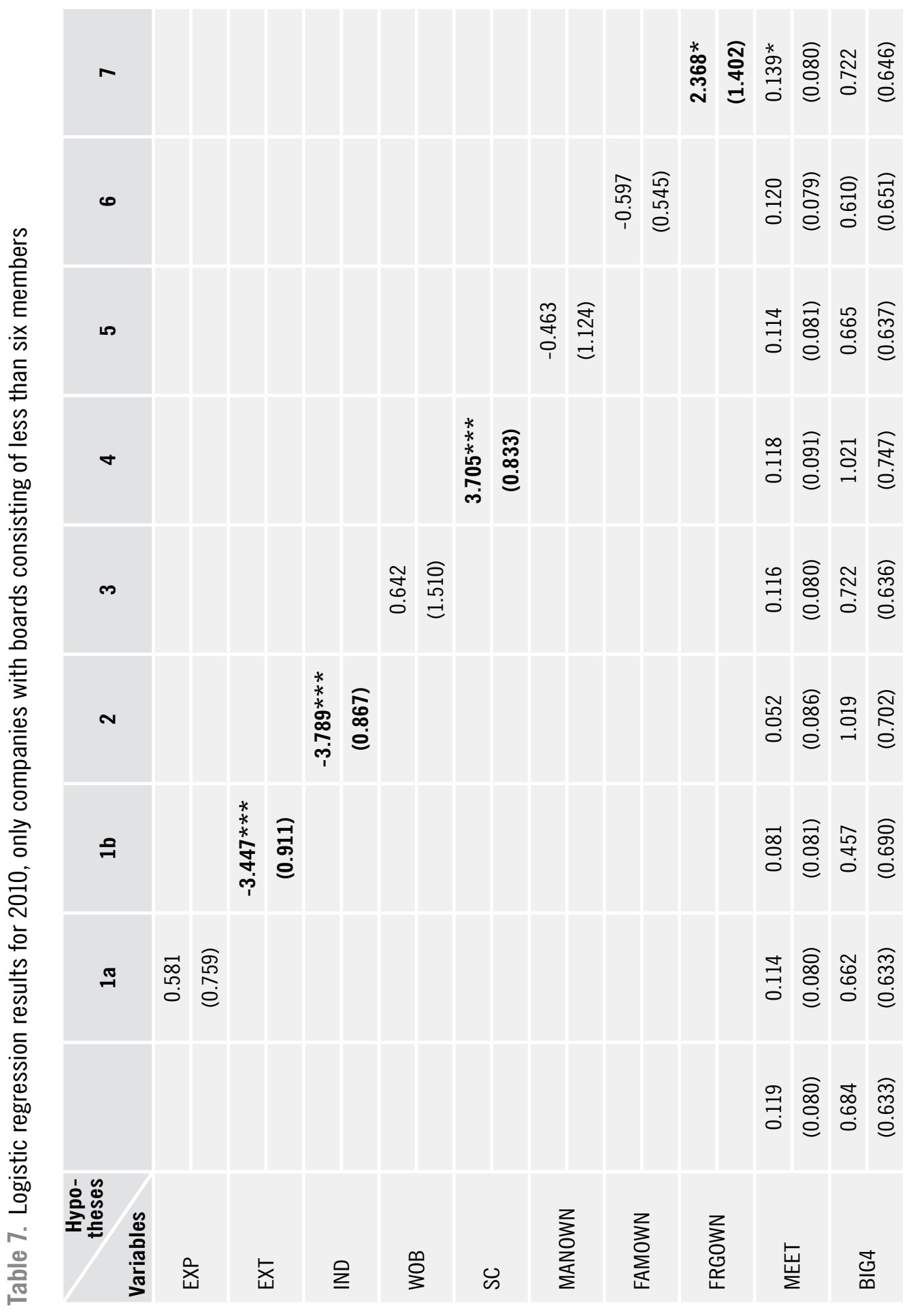




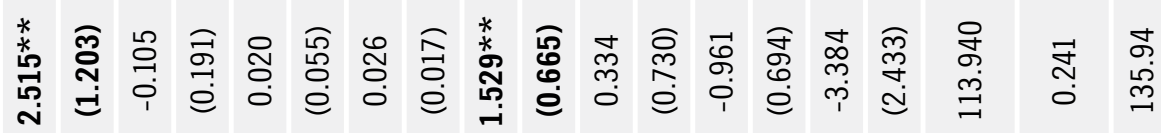

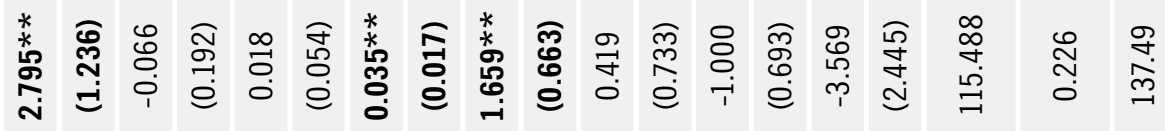

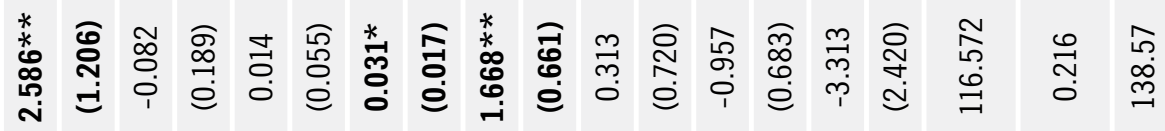

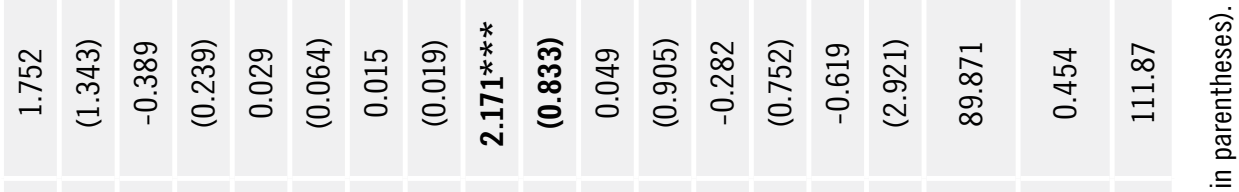

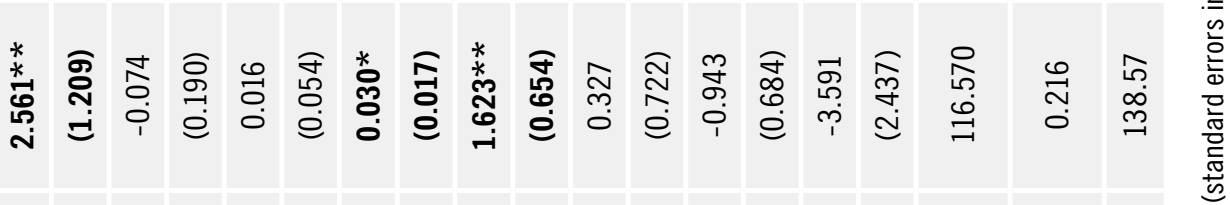

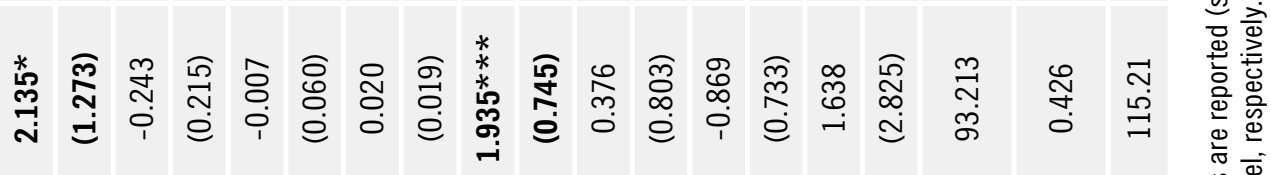

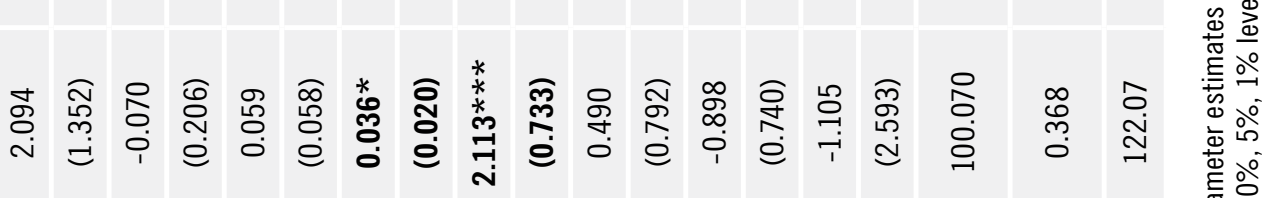

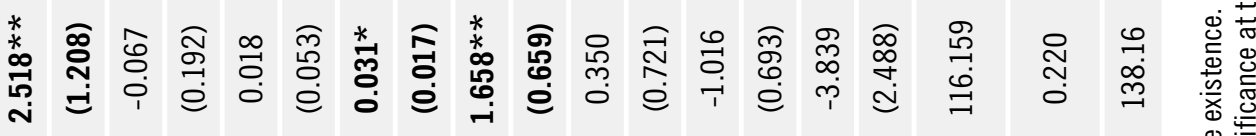

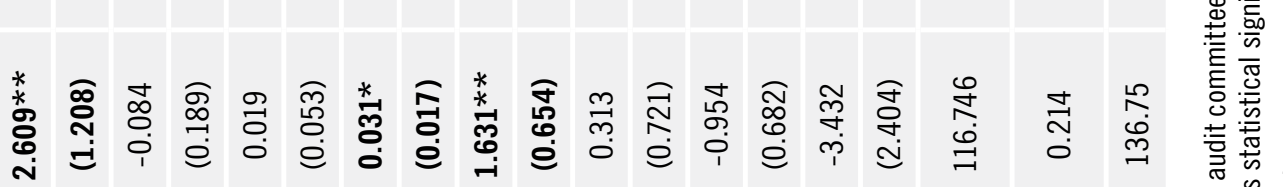

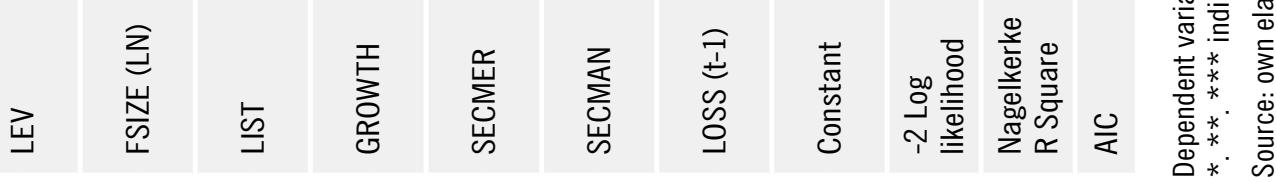




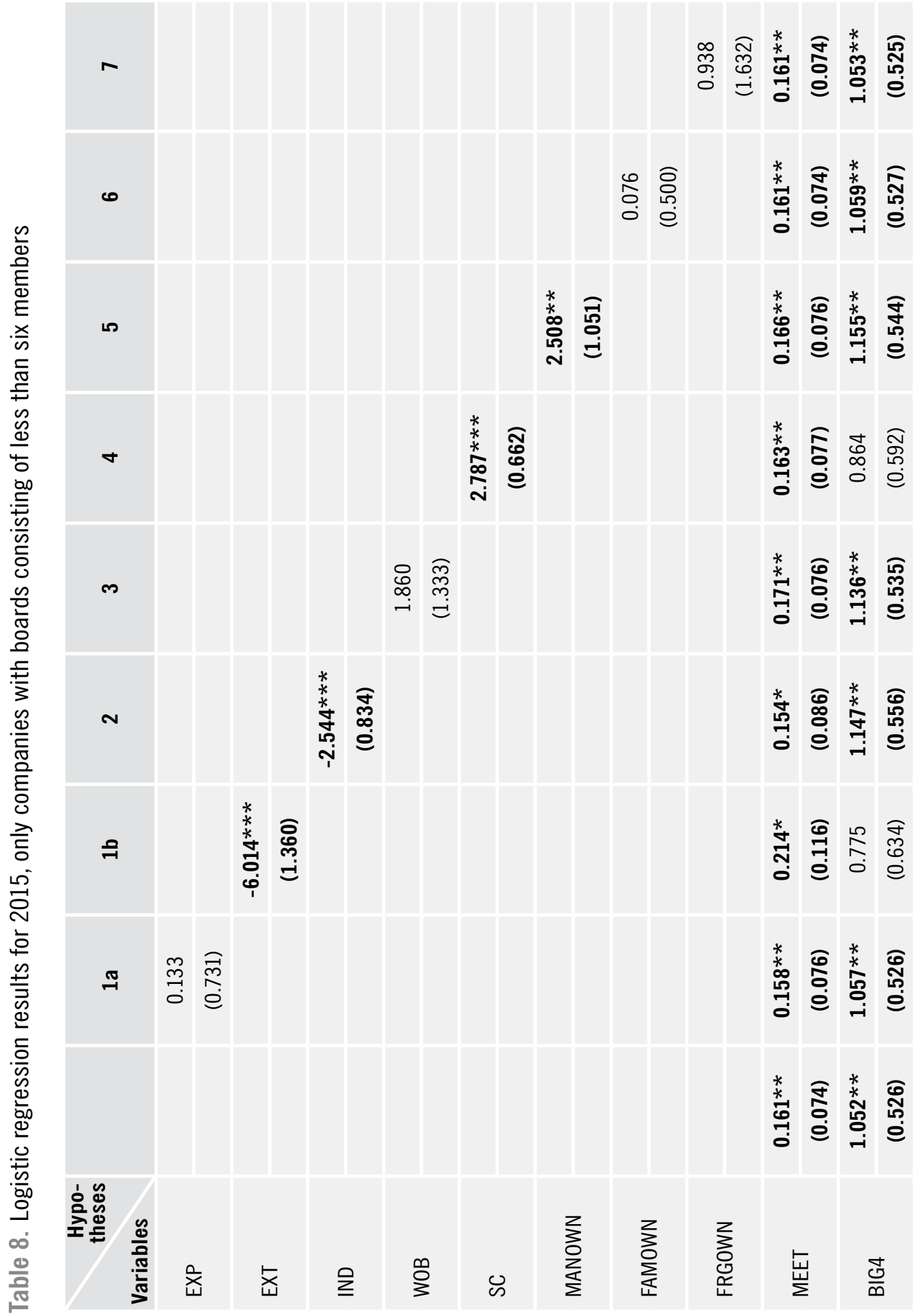




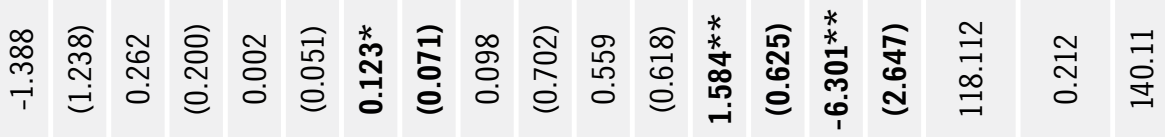

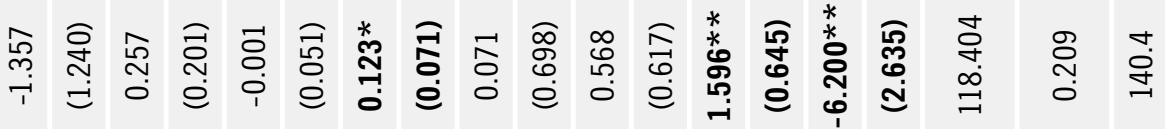

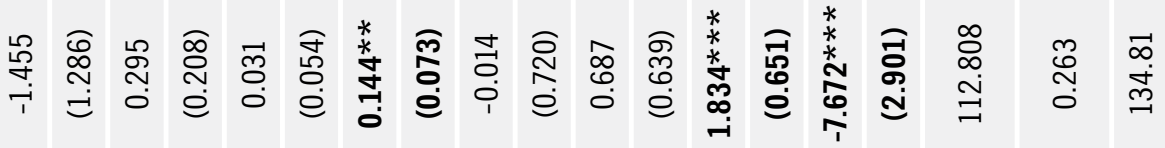

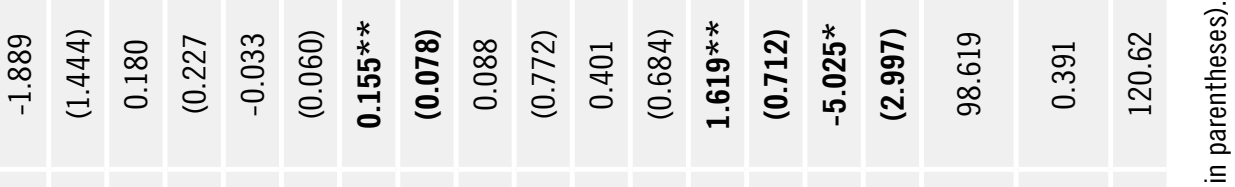

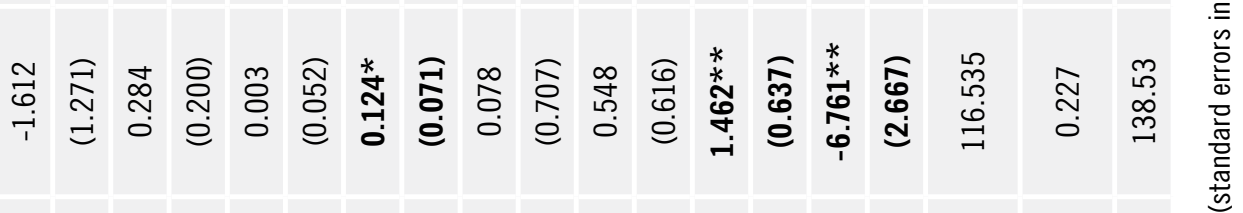

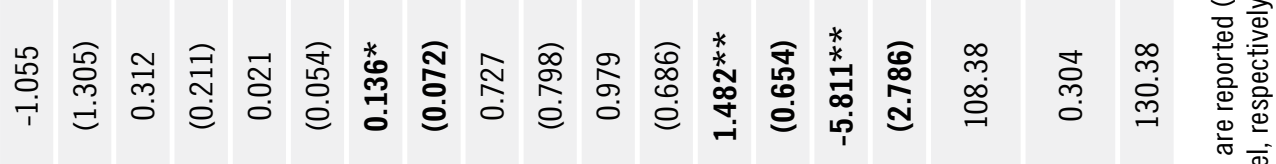

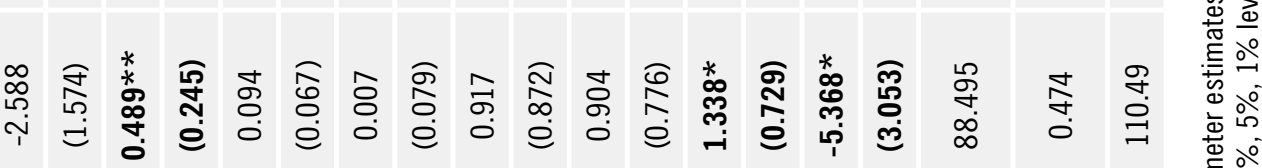

离 。

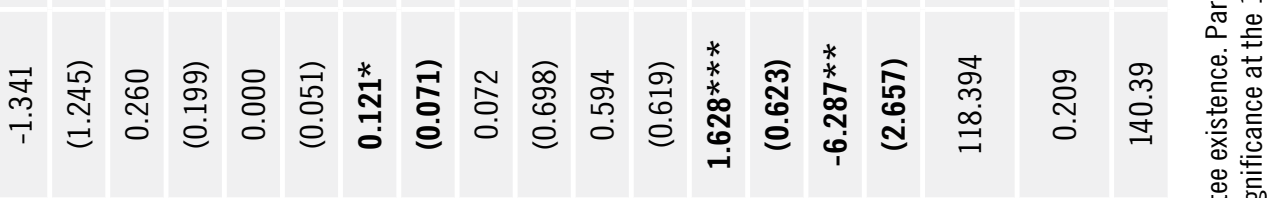

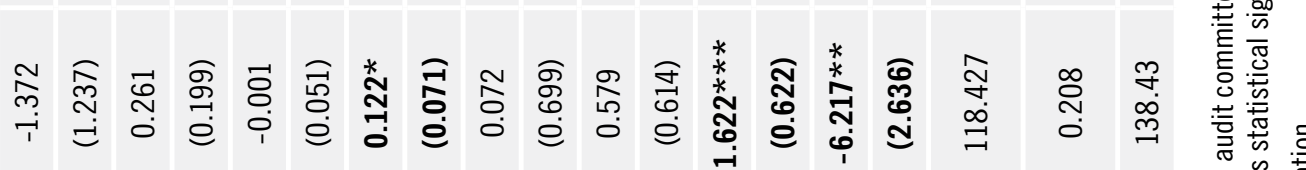

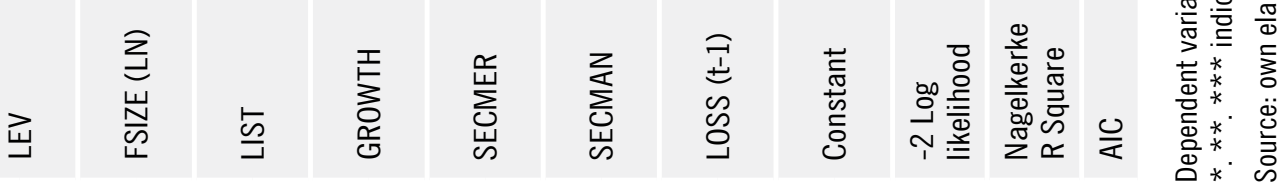


are an expensive monitoring mechanism (Pincus et al., 1989). According to the regulations, ACs should meet at least four times a year. Additional meetings could also be scheduled if necessary. However, these meetings are costly for companies. Therefore, we assume that if finance and accounting experts and independent members were on an SBs, there might have appeared no necessity to form an AC, as the company could have wanted to optimize costs.

The cultural aspect might also play an important role in explaining our findings as national culture can have strong effects on corporate governance (Li and Harrison, 2008). The prior literature is based on studies of the Anglo-Saxon model of corporate governance and suggests a positive correlation between AC formation and board member expertise and independence. This may not be the case in a different corporate governance model, especially when considering the aspect of culture. Compared to the Americans, Poles are more inclined to form groups with strong trust relationships (Olejniczak and Latusek-Jurczak, 2016). Board members may prefer to work collectively rather than to leave this important aspect of monitoring to a committee. This assumption can be confirmed by the positive correlation between foreign ownership and AC presence in 2008 and 2010. Our results related to foreign ownership agree with studies that claim we need effective corporate governance mechanisms to reduce agency conflicts between local and foreign investors (Bushman and Smith, 2003). Hence, companies with higher foreign ownership might be more willing to form ACs (Mangena and Tauringana, 2007). However, we notice no statically significant correlation in 2015.

Moreover, we also observe that in 2015 managerial ownership might also be an important factor in the AC formation decision. According to AT, managerial ownership might increase the probability that managers will manipulate accounting numbers to satisfy their interests (Piot, 2004). Some companies could have managed to form an AC after 2010 because after 2010 members of supervisory boards and management boards became aware of the amendment to the Polish Auditing Act of 2009, whose Article 4a was especially important (Journal of Laws, 2009). The Act states that the supervisory board is responsible on an equal basis with the management board for the reliability and quality of financial statements. Therefore, this regulation would predict that companies with higher managerial ownership should experience a higher probability of an AC presence.

Our results show that family firms are less likely to form an AC after the implementation of the EU Directive. This finding is consistent with prior studies (Menon and Williams, 1994). Many family members appoint themselves as board members of their firms, usually participate in firm monitoring processes, and have sufficient control 
(Chau and Leung, 2006). Moreover, the obligations to form an AC and nominate AC members who meet the criteria required by law can be troublesome mainly for companies controlled by families, in which the SBs are often elected from among family members - the main shareholders. An additional difficulty may also be the rigorous regulation of board members' independence (Journal of Laws, 2017).

Our results related to subcommittees are consistent with studies that claim the establishment of board subcommittees is strongly recommended as a potential mechanism for improving corporate governance (Spira and Bender, 2004). Companies that establish board subcommittees see that the action positively influences company performance (Premuroso and Bhattacharya, 2007; Huang et al., 2009). As such, the AC adds value to the monitoring aspect of the firm. This positive experience might influence the decision on AC formation.

According to control variables, company and board size were found to matter only in 2008, when AC formation was voluntary; these variables positively correlated with $\mathrm{AC}$ presence. The results suggest that the larger the company and the board, the higher the probability of an AC in the company. Following Pincus et al. (1989) and Piot (2014), we conclude that large firms, before the inclusion in new legislation on auditing (Journal of Laws, 2009), wanted to comply with corporate governance principles especially regarding the matter of independence. The new regulation imposes the formation of an AC according to the size of the SB. Therefore, we do not control for board size in 2010 and 2015 because - according to the regulation - AC formation depended on the number of SB members.

After the regulation came into force, we observe that the importance of other control variables also changed in terms of their impact on a firm's decision to form a committee. In 2010, we may notice that leverage, company growth ratio, and the sector in which the company operates gained in importance. Firms with higher leverage became more willing to form an AC. The reason might be that by forming an AC, the SB wanted to mitigate the risk of an increase in costs of debt financing associated with the increase in leverage (Piot, 2014). Moreover, we observe that companies with a higher growth ratio were more willing to form an AC. It might mean that if a firm has growth options then it might want to attract shareholders by following good corporate governance practices. Finally, we note the sector's impact. In 2010, companies in the merchandising sector were more willing to form an AC than those in the manufacturing sector.

In 2015, we notice a change in the impact of factors on the formation of the audit committee. The sector in which the company operates is no longer important, and what 
became more significant was the frequency of board meetings and the financial results achieved by the company. The reason for this positive effect of board meeting frequency on the AC formation might be that boards meet more frequently to monitor company performance adequately. Lipton and Lorsch (1992) show that boards that set a greater number of meetings are more diligent and better meet general stakeholder interests. Therefore, it may be so that such boards would also want to follow good corporate governance practices, i.e. form audit committees even in the absence of a regulatory necessity. Moreover, the supervisory board represents a monitoring and control mechanism seeking to analyze and evaluate the work of top management and to ensure profit maximization for shareholders (Donnelly and Mulcahy, 2008). Therefore, we may assume that a company's negative performance would encourage an SB to reinforce the company's monitoring system by forming an AC.

\section{Robustness Check}

To check the robustness of our main findings, we verified that outliers do not affect our results (and conclusions, in terms of hypotheses verification). We did this by ranking variables' values with the most asymmetric distributions (MEET, LEV, FRGOWN, SC) and constructing models with these ranked variables instead of the unranked values included in the models presented and discussed in the article. We report our results in Appendix A, Appendix B, and Appendix C. We find the regression results consistent with our main findings.

\section{Discussion and Conclusions}

Audit committees have attracted a lot of attention from researchers and regulators, as ACs are seen as an effective governance mechanism that allows for the better monitoring of managerial actions. With the amendment of the Eighth Company Directive, ACs became an essential and compulsory element of the Continental European system of corporate governance. Our study examined the factors that may influence the formation of ACs in Poland, a country and economy characterized by a two-tiered board system and a corporate governance system in which owners frequently hold large ownership stakes and control the company from within, where the system regarding incentives differs from that in the widely researched companies in the Anglo-Saxon context. Therefore, this article contributes to the literature on divergent practices related to ACs across European countries. 
The primary focus of the article is governance - and ownership-related factors. Contrary to most studies, our results indicate that the presence of members with experience and accounting and finance literacy - along with independent members - on an SB does not necessarily mean that a firm will be more likely to form an AC. This is a surprising finding which may indicate that in a particular corporate governance environment a board system of incentives may be different, leading to a different optimal governance package (Zaman and Valentinčič, 2011).

Moreover, an important contribution of this article is that indicates the positive association of AC formation with the existence of other board committees. This result suggests that companies with a positive experience related to the existence of other SB committees (e.g. remuneration, strategy, information technology) are more likely to help companies see an added value in forming an AC. When it comes to ownership structure, family ownership reduces the chances that a firm will have an AC, while foreign ownership increases these chances. However, we also observe that over the years a positive impact of managerial ownership on the formation of audit committees in companies has emerged.

Therefore, our findings agree with the prediction of selective adaptation theory, which suggests that adaption of an alien practice - in this case, an AC - depends on company characteristics and complementarity with local norms. In the light of selective adaptation theory, the findings of our study are not surprising. Companies with foreign ownership might be more likely to see the benefit of AC formation because of their experience from parent companies. Moreover, companies that have a positive experience with other supervisory committees might be more likely to adopt the regulation on AC as they may see added value from such a committee. On the other hand, governance characteristics like independent SB members or accounting and finance literacy are not necessarily sufficient reasons to form an AC, given the specific Polish corporate governance bundle. With big stakes of family and managerial ownership, the agency costs related to monitoring management actions may be limited. Therefore, the concept of an AC - as promoted in the Anglo-Saxon world - may not be perceived as beneficial and adding value to the monitoring efforts, leading to the generally weak acceptance of the proposed regulation.

The results of our study may also be important to the regulators who design enforcement actions aimed at the further promotion of ACs. Regulators might find our results useful because our study shows which firms responded positively to the new regulations on AC formation. Nevertheless, this study has some limitations. First, we focused 
only on governance and ownership factors as affecting the decision to form an AC. It is possible that what is equally important are economy-related factors, such as culture or economic history, or SB employment-related factors, such as the value of the supervisory board members' salaries or time worked in a particular board. Furthermore, future research might want to investigate how the share of foreign investors influences the introduction of good corporate governance practices in the company. Hence, it may be important to examine these factors in future studies. Second, a new Act of May 11, 2017, on Statutory Auditors, Audit Firms, and Public Oversight, changed the definitions of the type of companies that must form an AC (Journal of Laws, 2017). Therefore, it will be interesting to look at the influence of the new regulation on the AC formation process.

\section{References}

Abdeljawad, I., Oweidat, G.A.I., and Saleh, N.M. (2020). Audit committee versus other governance mechanisms and the effect of investment opportunities: evidence from Palestine. Corporate Governance (Bingley), 20(3), 527-544. https://doi.org/10.1108/CG06-2019-0185.

Adams, R., Gray, S., and Nowland, J. (2011). Does gender matter in the boardroom? Evidence from the market reaction to mandatory new director announcements. https://doi.org/10.2139/ssrn.1953152.

Adamska, A., Bohdanowicz, L., and Gad, J. (2017). Reakcje spółek publicznych na wprowadzenie obowiązku powoływania komitetu audytu. e-mentor, 4(71), 25-35. https://doi.org/10.15219/em71.1318.

Afify, H.A.E. (2009). Determinants of audit report lag: Does implementing corporate governance have any impact? Empirical evidence from Egypt. Journal of Applied Accounting Research, 10(1), 56-86. https://doi.org/10.1108/09675420910963397.

Ali, M.J., Singh, R.K.S., and Al-Akra, M. (2018). The impact of audit committee effectiveness on audit fees and non-audit service fees: Evidence from Australia. Accounting Research Journal, 31(2), 174-190.

Aluchna, M. (2013). Kobiety we władzach spółek: dyskusja rekomendacji Unii Europejskiej. Przegląd Organizacji, 1, 30-36. https://doi.org/10.33141/po.2013.01.06.

Archambeault, D., and DeZoort, F.T. (2001). Auditor opinion shopping and the audit committee: An analysis of suspicious auditor switches. International Journal of Auditing, 5(1), 33-52. https://doi.org/10.1111/1099-1123.00324.

Beasley, M.S., and Petroni, K.R. (2001). Board Independence and Audit-Firm Type. Auditing: A Journal of Practice and Theory, 20(1), 97-114. https://doi.org/10.2308/aud.2001.20.1.97.

Beasley, M.S., and Salterio, S.E. (2001). The relationship between board characteristics and voluntary improvements in audit committee composition and experience. Contemporary Accounting Research, 18(4), 539-570. https://doi.org/10.1506/RM1J-A0YM-3VMV-TAMV.

Bédard, J., and Gendron, Y. (2010). Strengthening the financial reporting system: Can audit committees deliver? International Journal of Auditing, 14(2), 174-210.

https://doi.org/10.1111/j.1099-1123.2009.00413.x.

Bekaert, G., and Harvey, C.R. (2002). Research in emerging markets finance: looking to the future. Emerging Markets Review, 3(4), 429-448. https://doi.org/10.1016/S1566-0141(02)00045-6. 
Belkhir, M. (2009). Board of directors' size and performance in the banking industry. International Journal of Managerial Finance, 5(2), 201-221, https://doi.org/10.1108/17439130910947903.

Best Practices Committee at the Corporate Governance Forum (2002). Best Practices in Public Companies in Poland. Warsaw: Corporate Governance Forum. Available at: http://www.ecgi.org/codes/documents/practices_2002.pdf.

Best Practice for GPW Listed Companies (2016). Warsaw Stock Exchange. Available at: https://www.gpw.pl/pub/GPW/o-nas/DPSN2016_EN.pdf.

Bohdanowicz, L. (2015). Struktury własnościowe spółek a rotacje prezesów zarządów - wyniki badań empirycznych. Zarzq̨dzanie i Finanse, 13(3), 165-181.

Bradbury, M.E. (1990). The incentives for voluntary audit committee formation. Journal of Accounting and Public Policy, 9(1), 19-36. https://doi.org/10.1016/0278-4254(90)90019-V.

Bradbury, M.E., Ma, D., and Scott, T. (2019). Explanations for not having an audit committee in a 'comply or explain' regime. Australian Accounting Review, 29(4), 649-662. https://doi.org/10.1111/auar.12241.

Bushman, R.M., and Smith, A.J. (2003). Transparency, financial accounting information, and corporate governance. Economic Policy Review, 9(1), 65-87.

Carson, E. (2002). Factors associated with the development of board subcommittees. Corporate Governance: An International Review, 10(1), 4-18. https://doi.org/10.1111/1467-8683.00263.

Cernat, L. (2004). The emerging European corporate governance model: Anglo-Saxon, Continental, or still the century of diversity? Journal of European Public Policy, 11(1), 147-166. https://doi.org/10.1080/1350176042000164343.

Chau, G.K., and Gray, S.J. (2002). Ownership structure and corporate voluntary disclosure in Hong Kong and Singapore. The International Journal of Accounting, 37(2), 247-265. https://doi.org/10.1016/S0020-7063(02)00153-X.

Chau, G., and Leung, P. (2006). The impact of board composition and family ownership on audit committee formation: Evidence from Hong Kong. Journal of International Accounting, Auditing and Taxation, 15(1), 1-15. https://doi.org/10.1016/j.intaccaudtax.2006.01.001.

Chen, L., Kilgore, A., and Radich, R. (2009). Audit committees: voluntary formation by ASX non-top 500. Managerial Auditing Journal, 24(5), 475-493. https://doi.org/10.1108/02686900910956829.

Collier, P. (1993). Factors affecting the formation of audit committees in major UK listed companies. Accounting and Business Research, 23(1), 421-430. https://doi.org/10.1080/00014788.1993.9729909.

Collier, P., and Zaman, M. (2005). Convergence in European corporate governance: The audit committee concept. Corporate Governance: An International Review, 13(6), 753-768. https://doi.org/10.1111/j.1467-8683.2005.00468.x.

Coval, J.D., and Moskowitz, T.J. (2001). The geography of investment: Informed trading and asset prices. Journal of Political Economy, 109(4), 811-841, https://doi.org/10.1086/322088.

Deli, D.N., and Gillan, S.L. (2000). On the demand for independent and active audit committees. Journal of Corporate Finance, 6(4), 427-445. https://doi.org/10.1016/S0929-1199(00)00016-X.

DeZoort, F.T., and Salterio, S.E. (2001). The effects of corporate governance experience and financial reporting and audit knowledge on audit committee members' judgments. Auditing: A Journal of Practice \& Theory, 20(2), 31-47. https://doi.org/10.2308/aud.2001.20.2.31.

Dobija, D. (2011). Auditing jako element ładu korporacyjnego. Zeszyty Teoretyczne Rachunkowości, 64(120), 25-37.

Dobija, D. (2015). Exploring audit committee practices: oversight of financial reporting and external auditors in Poland. Journal of Management \& Governance, 19(1), 113-143.

https://doi.org/10.1007/s10997-013-9281-6. 
Dwekat, A., Seguí-Mas, E., Tormo-Carbó, G., and Carmona, P. (2020). Corporate governance configurations and corporate social responsibility disclosure: Qualitative comparative analysis of audit committee and board characteristics. Corporate Social Responsibility and Environmental Management, 27(6), 2879-2892. https://doi.org/10.1002/csr.2009.

Fama, E.F., and Jensen, M.C. (1983). Agency problems and residual claims. The Journal of Law and Economics, 26(2), 327-349. https://doi.org/10.1086/467038.

García-Sánchez, I.M., Frias-Aceituno, J.V., and Garcia-Rubio, R. (2012). Determining factors of audit committee attributes: Evidence from Spain. International Journal of Auditing, 16(2), 184-213. https://doi.org/10.1111/j.1099-1123.2012.00451.x.

Guest, P.M. (2009). The impact of board size on firm performance: evidence from the UK. The European Journal of Finance, 15(4), 385-404. https://doi.org/10.1080/13518470802466121.

Hassan, Y., and Hijazi, R. (2015). Determinants of the voluntary formation of a company audit committee: evidence from Palestine. Asian Academy of Management Journal of Accounting and Finance, 11(1), 27-46.

Hillman, A.J., and Dalziel, T. (2003). Boards of directors and firm performance: Integrating agency and resource dependence perspectives. Academy of Management Review, 28(3), 383-396. https://doi.org/10.5465/amr.2003.10196729.

Huang, H., Lobo, G.J., and Zhou, J. (2009). Determinants and accounting consequences of forming a governance committee: Evidence from the United States. Corporate Governance: An International Review, 17(6), 710-727. https://doi.org/10.1111/j.1467-8683.2009.00769.x.

Jensen, M.C., and Meckling, W.H. (1976). Theory of the firm: Managerial behavior, agency costs and ownership structure. Journal of Financial Economics, 3(4), 305-360. https://doi.org/10.1111/j.1467-8683.2009.00769.x.

Johnson, J.L., Daily, C.M., and Ellstrand, A. E. (1996). Boards of directors: A review and research agenda. Journal of Management, 22(3), 409-438. https://doi.org/10.1177/014920639602200303.

Journal of Laws (2009, May 7). Certified Auditors, Their Self-Government, Entities Authorized to Audit Financial Statements and Public Supervision.

http://prawo.sejm.gov.pl/isap.nsf/download.xsp/WDU20090770649/T/D20090649L.pdf.

Journal of Laws (2017, May 11). The act of 11 May 2017 on Certified Auditors, Audit Firms and Public Supervision. http://prawo.sejm.gov.pl/isap.nsf/DocDetails.xsp?id=WDU20170001089.

Kaczmarek, S., Kimino, S., and Pye, A. (2012). Antecedents of board composition: The role of nomination committees. Corporate Governance: An International Review, 20(5), 474-489. https://doi.org/10.1111/j.1467-8683.2012.00913.x.

Köhler, A.G. (2005). Audit Committees in Germany - Theoretical Reasoning and Empirical Evidence. Schmalchenbach Business Review, 57(3), 229-252. https://doi.org/10.1007/BF03396715.

Kroll, M., Walters, B.A., and Wright, P. (2008). Board vigilance, director experience, and corporate outcomes. Strategic Management Journal, 29(4), 363-382. https://doi.org/10.1002/smj.649.

Latusek, D., and Olejniczak, T. (2016). Development of trust in low-trust societies. Polish Sociological Review, 195, 309-325.

Li, J., and Harrison, J.R. (2008). National culture and the composition and leadership structure of boards of directors. Corporate Governance: An International Review, 16(5), 375-385. https://doi.org/10.1111/j.1467-8683.2008.00697.x.

Lipton, M., and Lorsch, J.W. (1992). A modest proposal for improved corporate governance. The Business Lawyer, 59-77.

Mangena, M., and Tauringana, V. (2007). Disclosure, corporate governance and foreign share ownership on the Zimbabwe stock exchange. Journal of International Financial Management \& Accounting, 18(2), 53-85. https://doi.org/10.1111/j.1467-646X.2007.01008.x. 
Mangena, M., and Tauringana, V. (2008). Audit committees and voluntary external auditor involvement in UK interim reporting. International Journal of Auditing, 12(1), 45-63. https://doi.org/10.1111/j.1099-1123.2008.00369.x.

Mardjono, E.S., Chen, Y.S., and He, L.J. (2020). Earning management and the effect characteristics of audit committee, independent commissioners: Evidence from Indonesia. International Journal Of Business And Society, 21(2), 569-587. https://doi.org/10.5430/rwe.v11n3p108.

Mateescu, R.A. (2015). Corporate governance disclosure practices and their determinant factors in European emerging countries. Accounting and Management Information Systems, 14(1), 170.

Méndez, C.F., and García, R.A. (2007). The effects of ownership structure and board composition on the audit committee meeting frequency: Spanish evidence. Corporate Governance: An International Review, 15(5), 909-922. https://doi.org/10.1111/j.1467-8683.2007.00619.x.

Menon, K., and Williams, J.D. (1994). The use of audit committees for monitoring. Journal of Accounting and Public Policy, 13(2), 121-139. https://doi.org/10.1016/0278-4254(94)90016-7.

Nicholson, G.J., and Kiel, G.C. (2007). Can directors impact performance? A case-based test of three theories of corporate governance. Corporate Governance: An International Review, 15(4), 585-608. https://doi.org/10.1111/j.1467-8683.2007.00590.x.

Official Journal of the European Union (2006). Directive 2006/43/EC of the European Parliament and of the Council on Statutory Audits of Annual Accounts and Consolidated Accounts Amending Council Directives 78/660/EEC and 83/349/EEC and Repealing Council Directive 84/253/EEC. Available at: http://data.europa.eu/eli/dir/2006/43/2014-06-16.

Omer, T.C., Shelley, M.K., and Tice, F.M. (2020). Do director networks matter for financial reporting quality? Evidence from audit committee connectedness and restatements. Management Science, 66(8), 3361-3388. https://doi.org/10.1287/mnsc.2019.3331.

Pincus, K., Rusbarsky, M., and Wong, J. (1989). Voluntary formation of corporate audit committees among NASDAQ firms. Journal of Accounting and Public Policy, 8(4), 239-265. https://doi.org/10.1016/0278-4254(89)90014-8.

Piot, C. (2004). The existence and independence of audit committees in France. Accounting and Business Research, 34(3), 223-246. https://doi.org/10.1080/00014788.2004.9729966.

Post, C. and Byron, K. (2015). Women on boards and firm financial performance: a metaanalysis. Academy of Management Journal, 58(5), 1546-1571. https://doi.org/10.5465/amj.2013.0319.

Premuroso, R.F., and Bhattacharya, S. (2007). Is there a relationship between firm performance, corporate governance, and a firm's decision to form a technology committee? Corporate Governance: An International Review, 15(6), 1260-1276. https://doi.org/10.1111/j.1467-8683.2007.00645.x.

Putri, A.V., and Prasetyo, K. (2020). The Effect of Good Corporate Governance Mechanism on Earnings Management in Lq-45 Companies. Contemporary Economics, 14(4), 542-551. https://doi.org/10.11114/bms.v5i3.4313.

Salloum, C., Jabbour, G., Digout, J., and Gebrayel, E. (2015). Managerial dominance over the board and audit committee independence in financial institutions. Investment Management and Financial Innovations, 12(4), 33-42.

Shahid, M.S., and Abbas, M. (2019). Does corporate governance play any role in investor confidence, corporate investment decisions relationship? Evidence from Pakistan and India. Journal of Economics and Business, 105(C). https://doi.org/10.1016/j.jeconbus.2019.03.003.

Shleifer, A., and Vishny, R.W. (1986). Large shareholders and corporate control. Journal of Political Economy, 94(3), 461-488. https://doi.org/10.1086/261385.

Słomka-Gołębiowska, A., and Urbanek, P. (2016). Corporate boards, large blockholders and executive compensation in banks: Evidence from Poland. Emerging Markets Review, 28, 203-220. https://doi.org/10.1016/j.ememar.2016.08.001. 
Spira, L.F., and Bender, R. (2004). Compare and contrast: Perspectives on board committees. Corporate Governance: An International Review, 12(4), 489-499. https://doi.org/10.1111/j.1467-8683.2004.00389.x.

Srinidhi, B., Gul, F.A., and Tsui, J. (2011). Female directors and earnings quality. Contemporary Accounting Research, 28(5), 1610-1644. https://doi.org/10.1111/j.1911-3846.2011.01071.x.

Staszkiewicz, P. (2019). The application of citation count regression to identify important papers in the literature on non-audit fees. Managerial Auditing Journal, 34(1), 96-115. https://doi.org/10.1108/MAJ-05-2017-1552.

Wieczorek, A. (2012). Komitet audytu i komitet ds. wynagrodzeń w polskich bankach publicznych. Studia Prawno-Ekonomiczne, 85, 309-340.

Yeoh, P. (2007). Corporate governance models: Is there a right one for transition economies in Central and Eastern Europe? Managerial Law, 49(3), 57-75. https://doi.org/10.1108/03090550710816483.

Zaman Groff, M., and Valentinčič, A. (2011). Determinants of voluntary audit committee formation in a two-tier board system of a post-transitional economy - the case of Slovenia. Accounting in Europe, 8(2), 235-256. https://doi.org/10.1080/17449480.2011.621674.

Zhou, H., Owusu-Ansah, S. and Maggina, A. (2018). Board of directors, audit committee and firm performance: evidence from Greece. Journal of International Accounting, Auditing and Taxation, 31, 20-36. https://doi.org/10.1016/j.intaccaudtax.2018.03.002. 


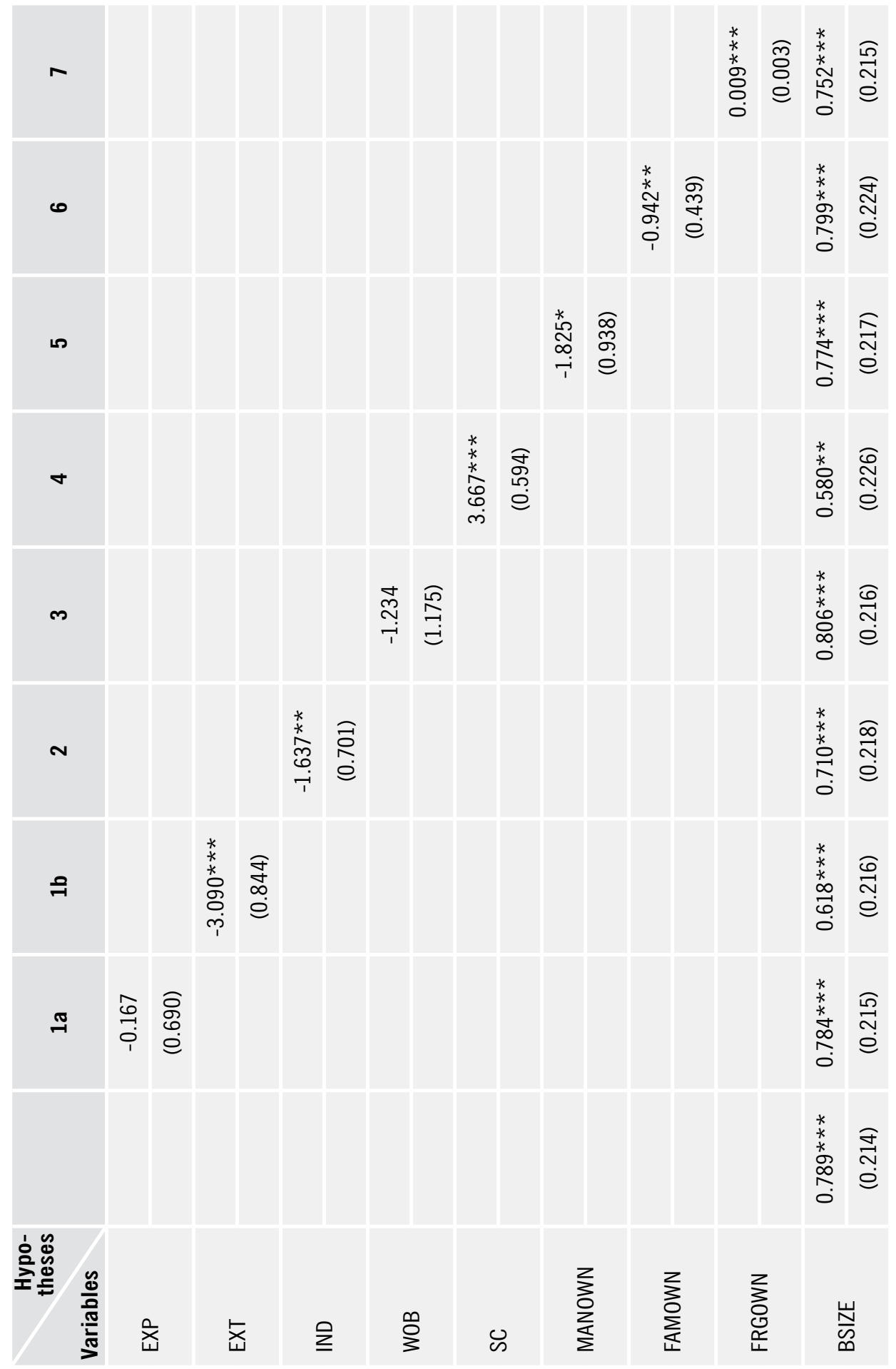




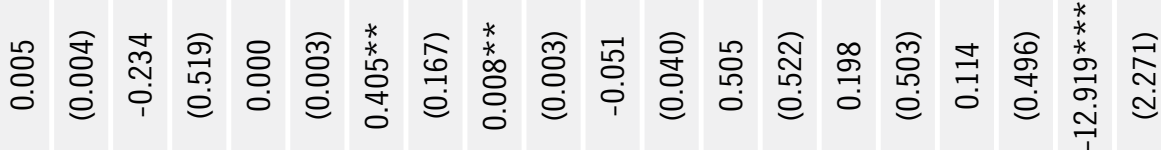

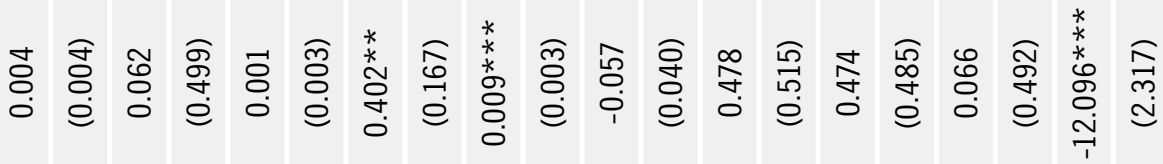

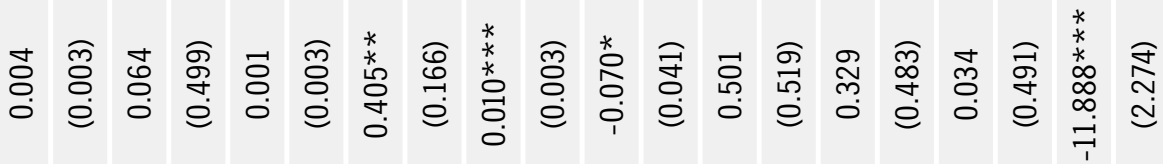

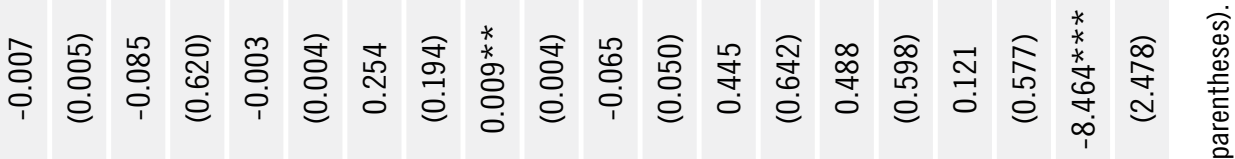

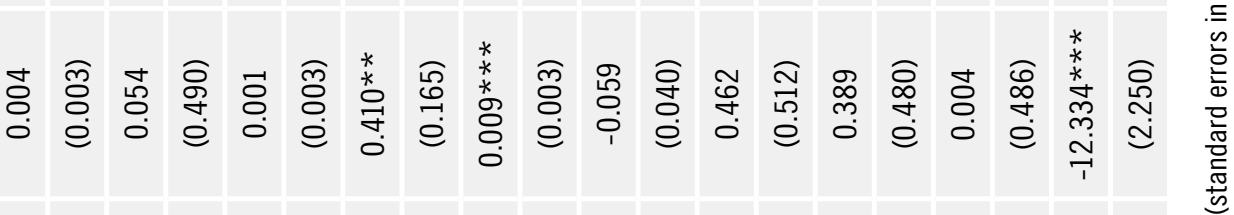

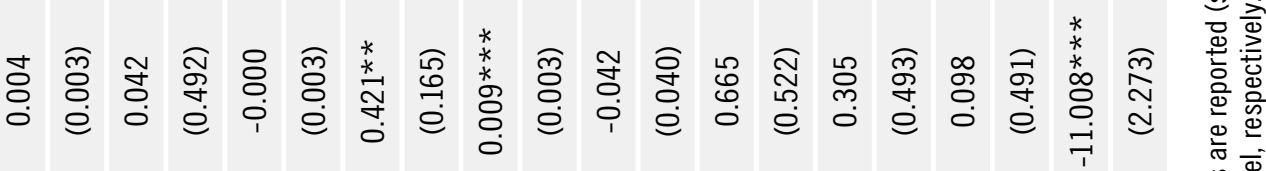

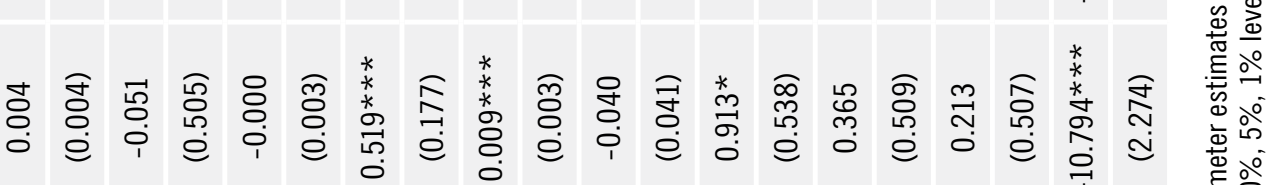
离 跑

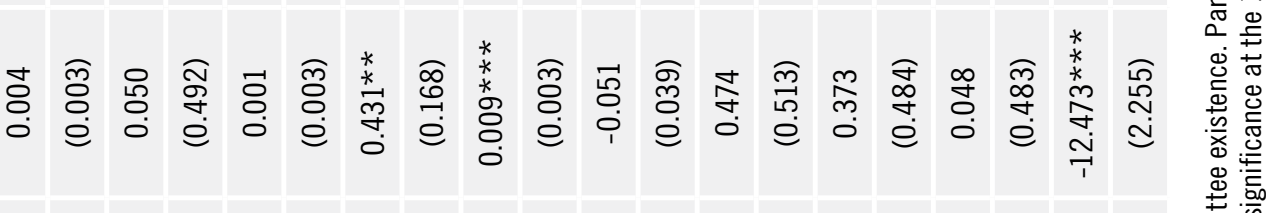

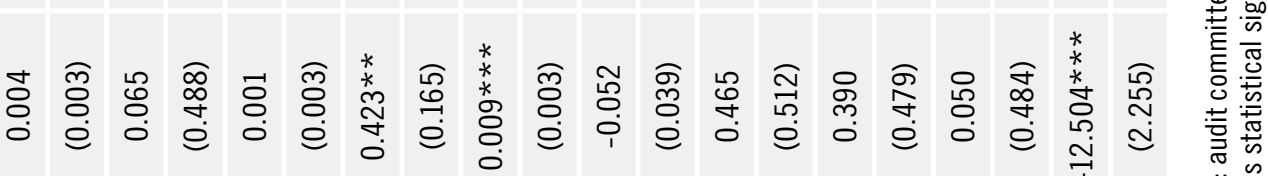

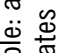

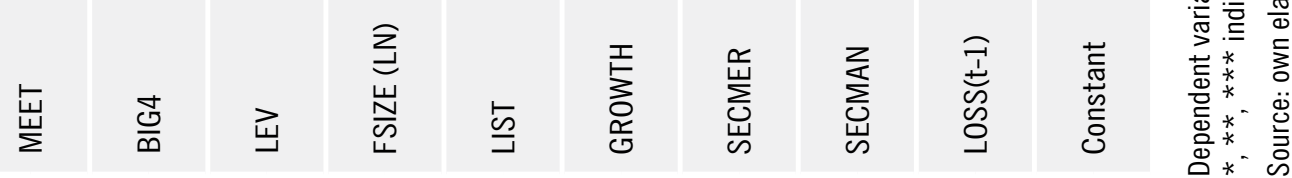




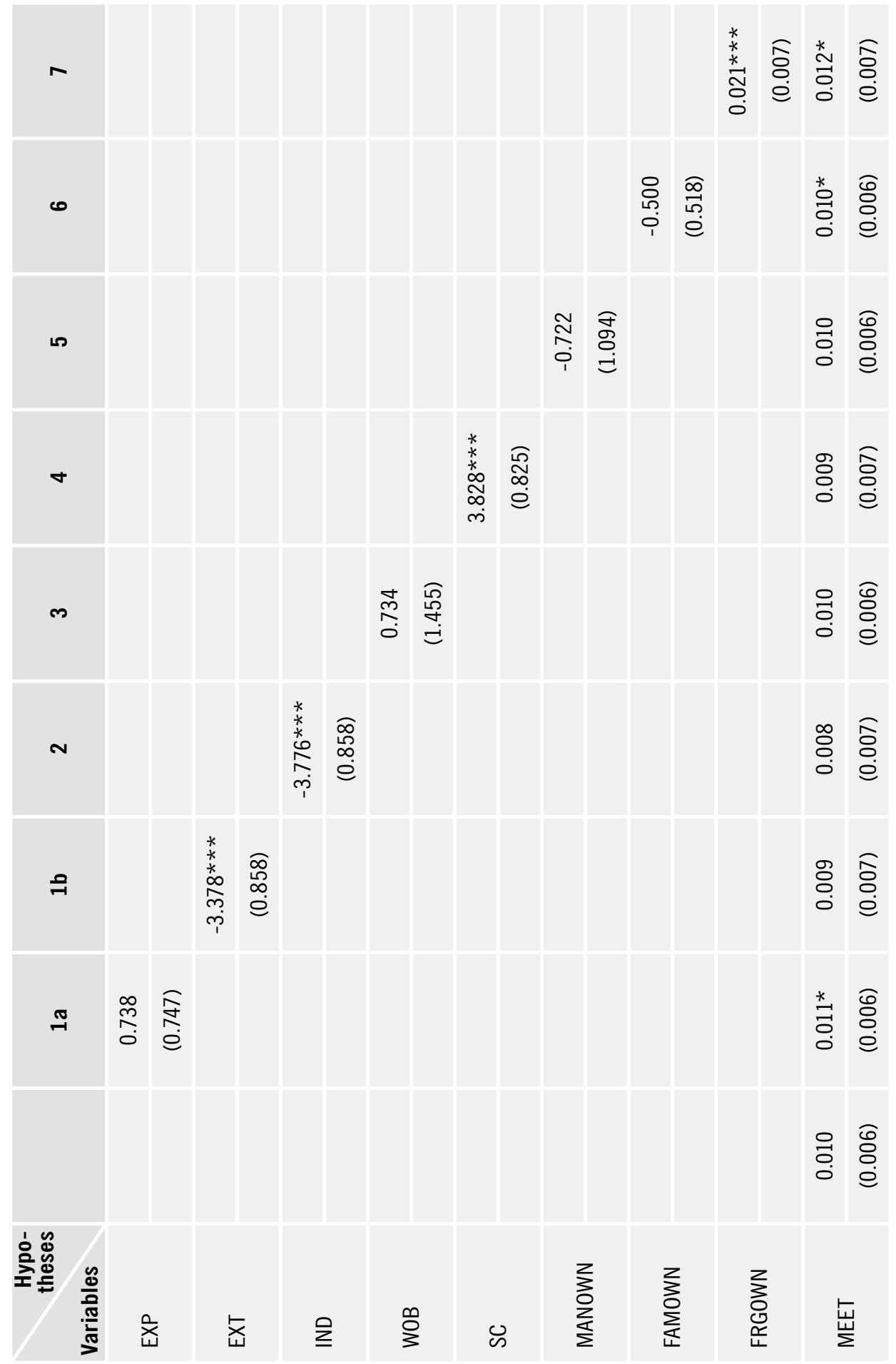




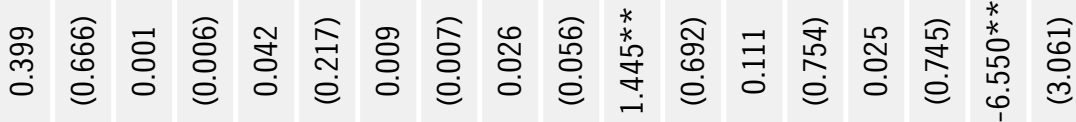

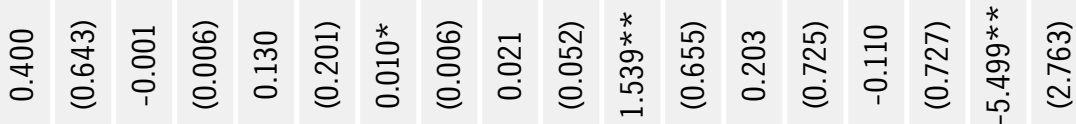

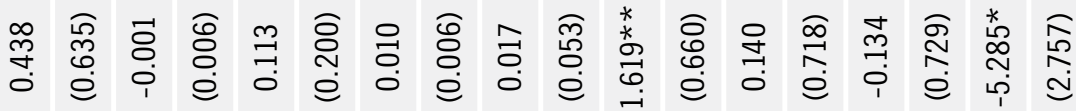

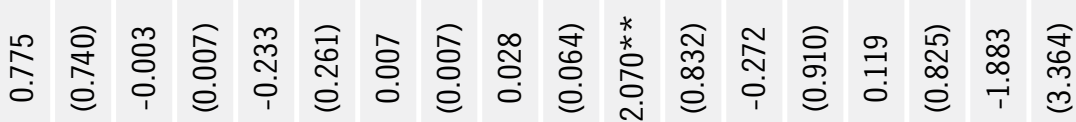

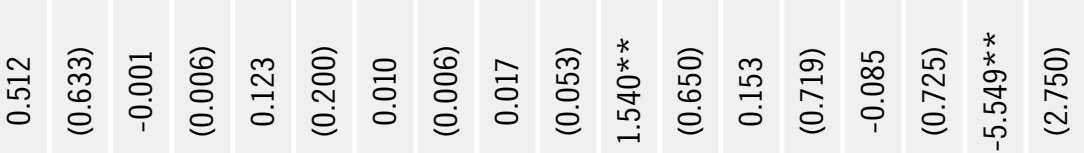

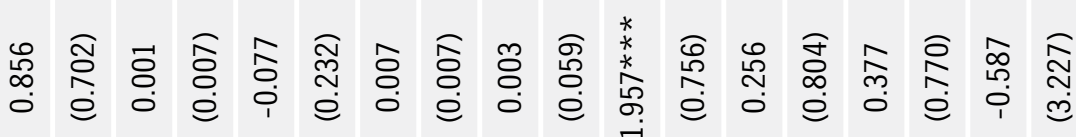

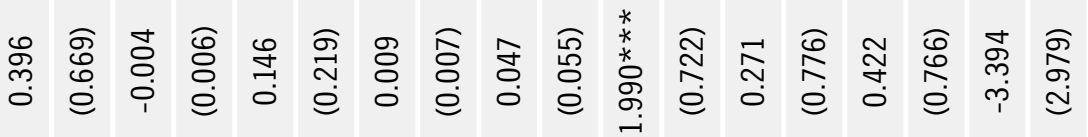

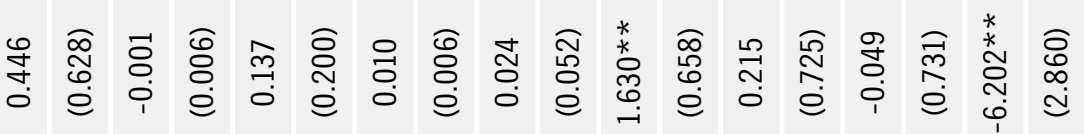




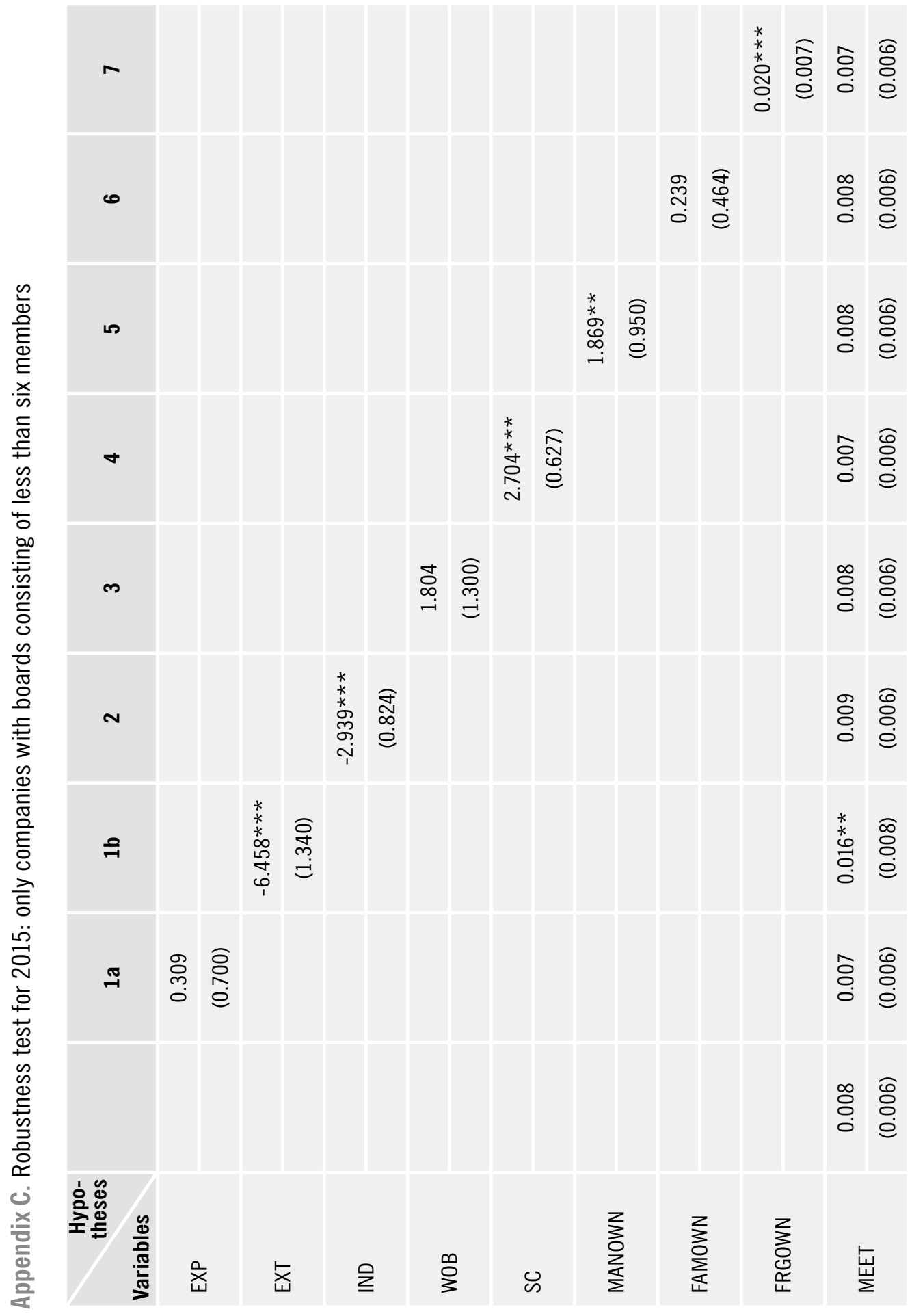




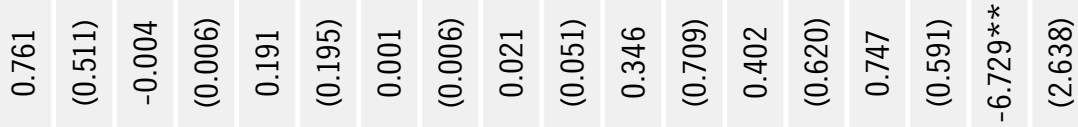

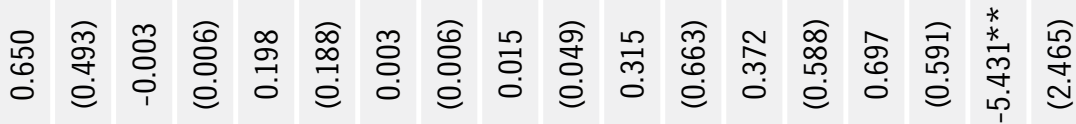

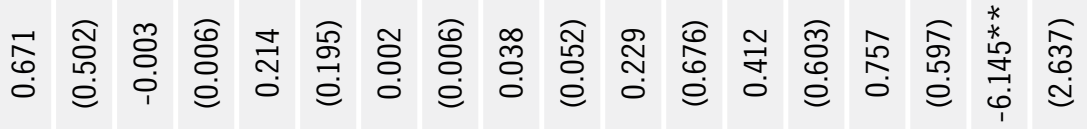

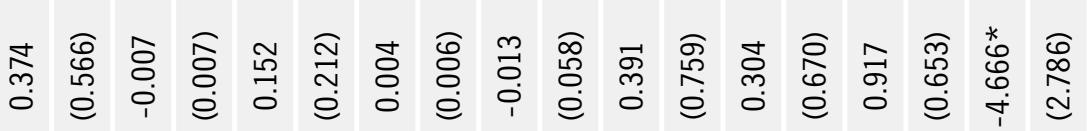

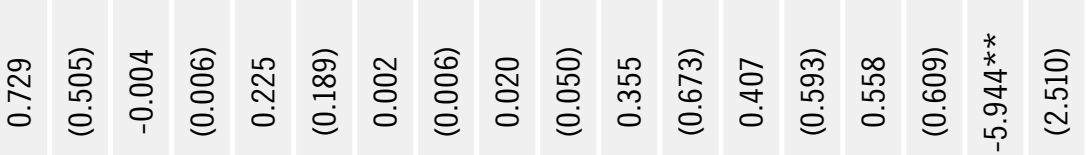

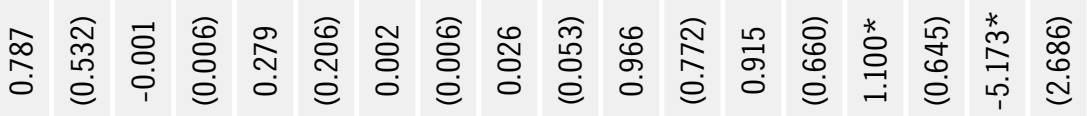

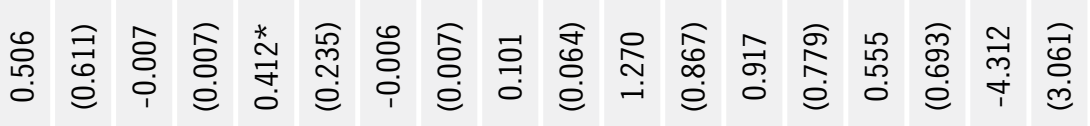

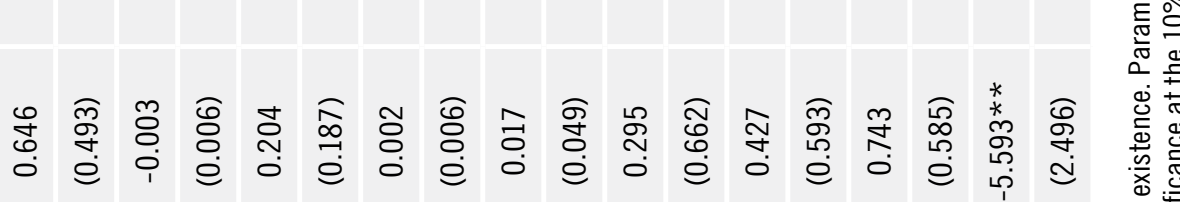

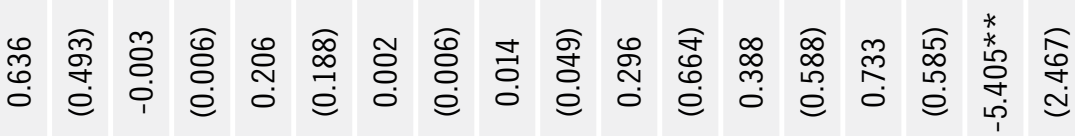

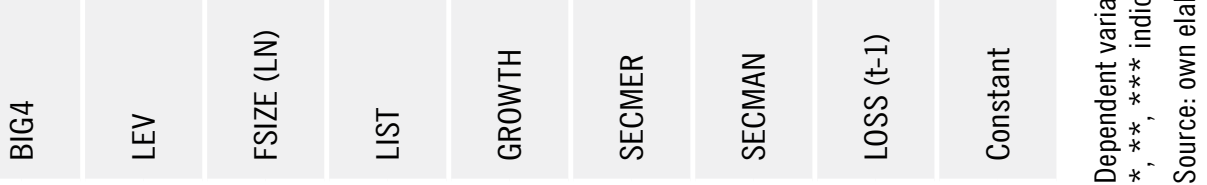

